\title{
Nutrients, Benthic Algae, and Stream Quality During Low Streamflow in the Palouse River Basin, Washington and Idaho
}

By Karen E. Greene, Mark D. Munn, and James C. Ebbert

U.S. GEOLOGICAL SURVEY

Water-Resources Investigations Report 96-4078

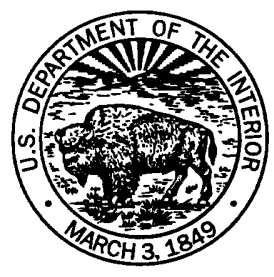




\title{
U.S. DEPARTMENT OF THE INTERIOR
}

\author{
BRUCE BABBITT, Secretary
}

\author{
U.S. GEOLOGICAL SURVEY
}

Gordon P. Eaton, Director

\section{ACKNOWLEDGMENTS}

The authors would like to acknowledge the following persons for their contributions to this report: Gary Holloway, USGS Hydrologic Technician, Tacoma, Washington, for assistance in all aspects of data collection; Greg Perry and Galen Schuster, USGS Hydrologic Technicians, Spokane, Washington, for data collection during the 24-hour study; James M. Bellatty, Idaho Department of Health and Welfare, Lewiston, Idaho, for providing discharge and concentration data for waste-water treatment plant outfalls; and Chauncey Anderson, USGS Hydrologist in Portland, Oregon, and Doyle Stephens, USGS Hydrologist in Salt Lake City, Utah, for technical review.

Any use of trade, product, or firm names is for descriptive purposes only and does not imply endorsement by the U.S. Geological Survey.

For additional information write to:

\section{District Chief}

U.S. Geological Survey

1201 Pacific Avenue, Suite 600

Tacoma, Washington 98402
Copies of this report may be purchased from:

\author{
U.S. Geological Survey \\ Branch of Information Services \\ Box 25286 \\ Denver, CO 80225
}

Information regarding the National Water-Quality Assessment (NAWQA) Program is available on the Internet via the World Wide Web. You may connect to the NAWQA Home Page using the Universal Resource Locator (URL) at:

<URL:http://wwwrvares.er.usgs.gov/nawqa/nawqa_home.html> 


\section{FOREWORD}

The mission of the U.S. Geological Survey (USGS) is to assess the quantity and quality of the earth resources of the Nation and to provide information that will assist resource managers and policymakers at Federal, State, and local levels in making sound decisions. Assessment of water-quality conditions and trends is an important part of this overall mission.

One of the greatest challenges faced by waterresources scientists is acquiring reliable information that will guide the use and protection of the Nation's water resources. That challenge is being addressed by.Federal, State, interstate, and local water-resource agencies and by many academic institutions. These organizations are collecting water-quality data for a host of purposes that include: compliance with permits and water-supply standards; development of remediation plans for a specific contamination problem; operational decisions on industrial, wastewater, or water-supply facilities; and research on factors that affect water quality. An additional need for water-quality information is to provide a basis on which regional and national-level policy decisions can be based. Wise decisions must be based on sound information. As a society we need to know whether certain types of water-quality problems are isolated or ubiquitous, whether there are significant differences in conditions among regions, whether the conditions are changing over time, and why these conditions change from place to place and over time. The information can be used to help determine the efficacy of existing water-quality policies and to help analysts determine the need for and likely consequences of new policies.

To address these needs, the Congress appropriated funds in 1986 for the USGS to begin a pilot program in seven project areas to develop and refine the National Water-Quality Assessment (NAWQA) Program. In 1991, the USGS began full implementation of the program. The NAWQA Program builds upon an existing base of water-quality studies of the USGS, as well as those of other Federal, State, and local agencies. The objectives of the NAWQA Program are to:
-Describe current water-quality conditions for a large part of the Nation's freshwater streams, rivers, and aquifers.

-Describe how water quality is changing over time.

-Improve understanding of the primary natural and human factors that affect water-quality conditions.

This information will help support the development and evaluation of management, regulatory, and monitoring decisions by other Federal, State, and local agencies to protect, use, and enhance water resources.

The goals of the NAWQA Program are being achieved through ongoing and proposed investigations of 60 of the Nation's most important river basins and aquifer systems, which are referred to as study units. These study units are distributed throughout the Nation and cover a diversity of hydrogeologic settings. More than two-thirds of the Nation's freshwater use occurs within the 60 study units and more than two-thirds of the people served by public water-supply systems live within their boundaries.

National synthesis of data analysis, based on aggregation of comparable information obtained from the study units, is a major component of the program. This effort focuses on selected water-quality topics using nationally consistent information. Comparative studies will explain differences and similarities in observed water-quality conditions among study areas and will identify changes and trends and their causes. The first topics addressed by the national synthesis are pesticides, nutrients, volatile organic compounds, and aquatic biology. Discussions on these and other waterquality topics will be published in periodic summaries of the quality of the Nation's ground and surface water as the information becomes available.

This report is an element of the comprehensive body of information developed as part of the NAWQA Program. The program depends heavily on the advice, cooperation, and information from many Federal, State, interstate, Tribal, and local agencies and the public. The assistance and suggestions of all are greatly appreciated.

Robert M. Hirsch Chief Hydrologist 


\section{CONTENTS}

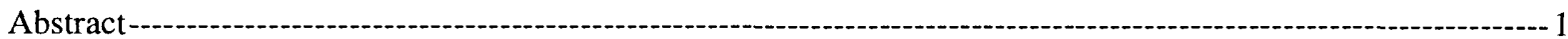

Introduction --

Study area --on-

Study design and methods -

Site selection -

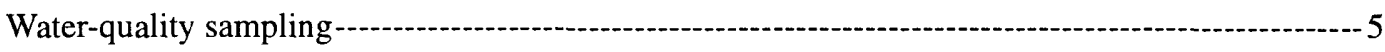

Measuring growth of benthic algae and identifying controlling variables -

Calculation of nutrient loads--

Inputs and export of nutrients --.-.- 8

Nutrients and stream quality during low streamflow -

Spatial variations -

Chloride as a possible indicator of waste-water treatment plant effluent -........-...- 13

Dissolved oxygen concentrations and pH-

Nutrients in the Palouse River-- 13

Nutrients in the South Fork system -

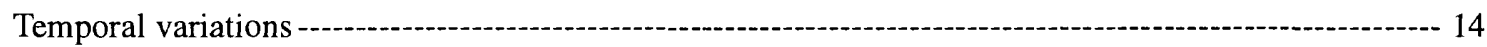

Nutrients in the Palouse River- 15

Nutrients in the South Fork system - 15

Dissolved oxygen concentrations and $\mathrm{pH}-\mathrm{-}-\mathrm{-}$

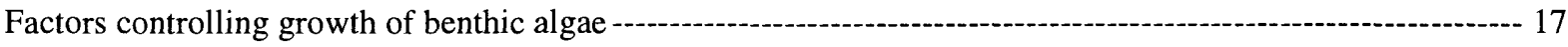

Palouse River -- 17

South Fork system -- 22

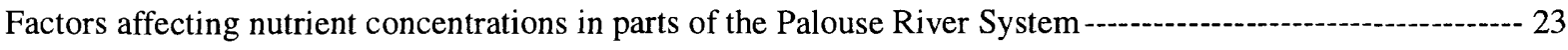

Loss of inorganic nitrogen in the South Fork system - - 23

Loss of orthophosphate in the Palouse River downstream from Colfax --o-

Summary ---

Cited references -...-..--.-- 29

Appendix A.--Selected data, including field measurements and concentrations of dissolved constituents, collected during the synoptic sampling August 1-5, 1994, and concentrations of chlorophyll $a$ and ash-free dry weight measured for an 8-week colonization period, July-September 1994, at sites in the

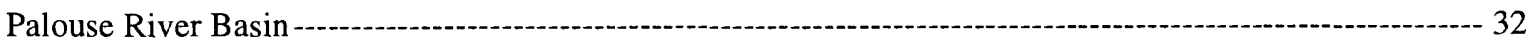

Appendix B.--Selected results from the 24-hour study conducted at five sites in the Palouse River Basin August 2-3, 1994 -- 34

Appendix C.--Development of mass-balance equations used to estimate dilution of orthophosphate in the Palouse River --.--on 38 


\section{FIGURES}

1. Map showing sampling sites, land use, and location of waste-water treatment plants in the Palouse River Basin --.-- 3

2. Graph showing continuous streamflow at two sites in the Palouse River Basin, August 1-5, 1994--.---.--4

3. Bar charts showing monthly mean discharges of nitrogen, phosphorus, and water from the Moscow and Pullman waste-water treatment plants and at the South Fork Palouse River at Colfax

4. Bar chart showing total dissolved organic and inorganic nitrogen concentrations in synoptic samples collected August 1-5, 1994, at sites in the Palouse River Basin--.-.-.- 11

5. Graphs showing concentrations of dissolved inorganic nutrients at sites in the Palouse River Basin, August 1-5, 1994--.- 12

6. Graph showing concentrations of chloride at sites in the Palouse River Basin, August 1-5, 1994 ------- 13

7. Graph showing 24-hour changes in dissolved oxygen concentrations at two sites on the South Fork Palouse River and three sites on the Palouse River, August 2-3, 1994

8. Graph showing molar ratios of inorganic nitrogen to orthophosphate for sites in the Palouse River Basin --.-- 18

9. Graph showing concentrations of chlorophyll $a$ in benthic algae accrued on artificial substrates, during an 8-week colonization period, during low streamflow conditions at sites in the Palouse River Basin, 1994-

10. Graphs showing concentrations of chlorophyll $a$ in relation to four correlated variables for sites in the Palouse River Basin

11. Graphs showing values of variables correlated with chlorophyll $a$, measured during low streamflow at sites in the Palouse River Basin, August 1-5, 1994

12. Schematic representation of movement of surface water, ground water, and a solute into and out of a river reach-1- 24

\section{TABLES}

1. Sites in the Palouse River Basin, in downstream order-a. 6

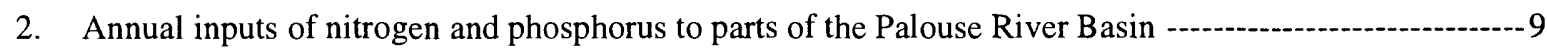

3. Statistical relationships between chlorophyll $a$ concentrations and inorganic nitrogen concentrations and solar energy at sites in the Palouse River Basin during low streamflow, July-September 1994 -- 20

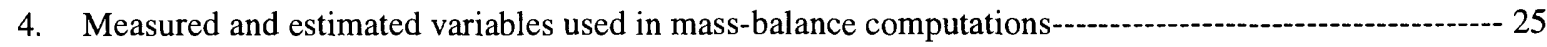

5. Results of mass-balance computations-- 26 
CONVERSION FACTORS AND VERTICAL DATUM

\begin{tabular}{rll} 
Multiply & By & To obtain \\
\hline centimeter $(\mathrm{cm})$ & 0.3937 & inch \\
square centimeter $\left(\mathrm{cm}^{2}\right)$ & 0.1550 & square inch \\
square meter $\left(\mathrm{m}^{2}\right)$ & 0.0929 & square foot \\
kilometer $(\mathrm{km})$ & 1.6093 & mile \\
square kilometer $\left(\mathrm{km}^{2}\right)$ & 0.3861 & square mile \\
liter per second $(\mathrm{L} / \mathrm{s})$ & 15.85 & gallon per minute \\
meter per second $(\mathrm{m} / \mathrm{s})$ & 3.281 & foot per second \\
ton $(\mathrm{metric})$ & 2,205 & pound \\
degrees Celsius $\left({ }^{\circ} \mathrm{C}\right)$ & ${ }^{\circ} \mathrm{F}=(9 / 5)^{\circ} \mathrm{C}+32$ & degrees Fahrenheit \\
& ${ }^{\circ} \mathrm{C}=(5 / 9)\left[{ }^{\circ} \mathrm{F}-32\right]$ & \\
\hline
\end{tabular}

Additional Conversions

$1 \mathrm{mg} / \mathrm{L}=1 \mathrm{ppm}$ (parts per million)

$1 \mu \mathrm{g} / \mathrm{L}=1 \mathrm{ppb}$ (parts per billion)

$0.2259 \mathrm{mg} / \mathrm{L}$ as $\mathrm{N}=1 \mathrm{mg} / \mathrm{L}$ as $\mathrm{NO}_{3}$

$0.3045 \mathrm{mg} / \mathrm{L}$ as $\mathrm{N}=1 \mathrm{mg} / \mathrm{L}$ as $\mathrm{NO}_{2}$

$0.7778 \mathrm{mg} / \mathrm{L}$ as $\mathrm{N}=1 \mathrm{mg} / \mathrm{L}$ as $\mathrm{NH}_{4}$

$0.3261 \mathrm{mg} / \mathrm{L}$ as $\mathrm{P}=1 \mathrm{mg} / \mathrm{L}$ as $\mathrm{PO}_{4}$

$1 \mathrm{Mgal} / \mathrm{d}=1.5472 \mathrm{ft}^{3} / \mathrm{s}$

$1 \mathrm{ft}^{3}=7.48$ gal
Abbreviations

milligrams per tenth of square meter $\left(\mathrm{mg} / 0.1 \mathrm{~m}^{2}\right)$

microSiemens per centimeter $(\mu \mathrm{S} / \mathrm{cm})$

micrograms per liter $(\mu \mathrm{g} / \mathrm{L})$

milligrams per liter $(\mathrm{mg} / \mathrm{L})$ 


\title{
Nutrients, Benthic Algae, and Stream Quality During Low Streamflow in the Palouse River Basin, Washington and Idaho
}

\author{
By Karen E. Greene, Mark D. Munn, and James C. Ebbert
}

\begin{abstract}
As part of the U.S. Geological Survey's National Water-Quality Assessment Program, cumulative downstream effects of nutrients from point and nonpoint sources during low streamflows in the Palouse River Basin were investigated during July-September in 1994, a dry year. More than 98 percent of the total nitrogen and phosphorus inputs to the Palouse River drainage basin is from nonpoint sources such as fertilizers, atmospheric deposition, and livestock; however, much of this input never reaches the river, and only about 5 percent and 4 percent of the annual nitrogen and phosphorus inputs to the Palouse River drainage basin is exported in surface-water discharge during an average flow year. The highest nutrient concentrations in the basin, the largest diel swings in dissolved oxygen, and the most prolific growth of aquatic plants were in the South Fork system (Paradise Creek and the South Fork Palouse River), which runs through urban areas and receives effluent from the two largest wastewater treatment plants in the basin. During low streamflow, the water in the South Fork system is mostly treatment plant effluent. The Washington State ammonia toxicity standard was exceeded at the site below the Moscow treatment plant on Paradise Creek.
\end{abstract}

Diel changes in nutrient and dissolved oxygen concentrations were observed during a 24-hour study at 5 of the 19 sites included in the investigation. At the three sites below treatment plants, nutrient concentrations were lowest between 5 and $6 \mathrm{p} . \mathrm{m}$. and highest between 5 a.m. and noon, possibly indicating diurnal variation in the rate of uptake of nutrients by aquatic plants. Large diel swings in dissolved oxygen concentrations (changes of $11.4 \mathrm{mg} / \mathrm{L}$ (milligrams per liter), $14.2 \mathrm{mg} / \mathrm{L}$, and $14.7 \mathrm{mg} / \mathrm{L}$ ) were observed at the three sites downstream from treatment plants, and diel changes of $8.7 \mathrm{mg} / \mathrm{L}$ and $4.6 \mathrm{mg} / \mathrm{L}$ were observed at the site on the Palouse River above the confluence with the South Fork system and at the downstream site on the Palouse River. At sites throughout the study area, Washington State standards for minimum dissolved oxygen concentration and maximum $\mathrm{pH}$ were not met.

Growth of benthic algae, as indicated by concentrations of chlorophyll $a$, was measured during an 8-week colonization period using artificial substrates. Multiple regression models were developed to determine what combination of nutrients and physical variables most accounted for growth of benthic algae. Inorganic nitrogen was the limiting nutrient in the Palouse River; and solar energy, water temperature, and water velocity were physical factors influencing the growth of benthic algae on a more local, reach-specific scale. Molar ratios of inorganic nitrogen to orthophosphate ( $\mathrm{N}: \mathrm{P}$ ratios) were less than 8 at all sites on the Palouse River and in the South Fork system, further indicating nitrogen limitation of growth of benthic algae in most of the basin. However, chlorophyll $a$ in the South Fork system was not significantly correlated with any of the measured parameters, indicating that nutrient loading in this part of the basin exceeded the nutrient requirements of aquatic plants.

Most of the inorganic nitrogen contributed by treatment plants was removed from the South Fork system before the confluence of the South Fork Palouse River with the Palouse River; however, orthophosphate concentrations remained high until much farther downstream. Changes in growth of benthic algae, even considering the 
increased growth of aquatic macrophytes in the lower South Fork Palouse River, did not account for the loss of inorganic nitrogen in the South Fork system: denitrification probably accounted for most of the additional nitrogen removal during the extreme low streamflows and low dissolved oxygen conditions observed during the study. The decrease in orthophosphate concentrations in the reach of the Palouse River downstream from the Colfax treatment plant was caused by some combination of dilution by ground-water seepage, uptake by aquatic plants, and sorption to streambed and suspended sediments; decreasing chloride concentrations in the reach indicated that dilution accounted for most of this decrease. These mitigating processes were active during the period of this study, but more data are needed to determine how regularly they occur in the river.

\section{INTRODUCTION}

Stream quality in the Palouse River Basin varies as a result of spatial changes in land use, sources of pollutants, and seasonal changes in streamflow conditions. During summer baseflow, nutrient inputs from waste-water treatment plant (WWTP) effluent have considerable impact on stream quality, whereas during winter and spring months, the effects of surface runoff from agricultural land increase because runoff contributes to nutrient loading when rainstorms and snowmelt wash eroded soil into streams (Greene and others, 1994). Cattle-grazing is an important source of pollution on a local scale, and shallow ground water contributes relatively minor inputs of nutrients to surface water. Although on an annual basis most nutrient inputs to the basin are from these nonpoint sources, extensive growth of aquatic plants and large diel swings in dissolved oxygen concentrations during low streamflows are more often attributed to point sources of nutrients such as WWTPs, which cause local streamquality problems in some reaches of the Palouse River. The downstream extent of these point-source effects in the Palouse River is unknown. As part of the U.S. Geological Survey's National Water Quality Assessment (NAWQA) program, an assessment of nutrient loads and downstream effects in the basin is underway.

Previous studies in the basin have focused on short stream reaches that receive discharges from WWTPs (Joy, 1987), and more specifically on the levels of ammonia in WWTP effluent (Pelletier, 1993). However, stream reaches throughout the basin are influenced to varying degrees by WWTP discharges and agricultural practices, and WWTP effluent may affect the river far downstream. In order to manage stream quality in the basin, information is needed on large-scale and local variations in nutrient loading, cumulative downstream effects, and the magnitude of nutrient removal by multiple mechanisms including uptake by aquatic plants, denitrification, and losses to the ground-water system.

The objectives of this report are (1) to estimate the relative contributions of point and nonpoint inputs of nitrogen and phosphorus nutrients in the basin; (2) to assess spatial and temporal variations in nutrient concentrations; (3) to compare parts of the Palouse River affected by point and nonpoint sources of nutrients during low streamflows, when the point sources are most influential; (4) to determine what nutrients and physical factors control growth of benthic algae in the basin; and (5) to improve the conceptual understanding of large-scale nutrient sources and losses in the Palouse River system during low streamflows.

\section{Study Area}

The Palouse River Basin is located in semi-arid eastern Washington and mountainous northern Idaho (fig. 1). Most of the $6,500-\mathrm{km}^{2}$ basin has rich loess soils, warm temperatures, and long, sunny summer days. Average air temperatures range from $14^{\circ} \mathrm{C}$ to $22^{\circ} \mathrm{C}$ from July through September (National Oceanic and Atmospheric Administration, 1991), and daylight lasts as long as 16 hours during those months. Average annual precipitation in the basin decreases from more than $64 \mathrm{~cm}$ at the headwaters in the mountains to about $33 \mathrm{~cm}$ at the mouth of the river (Tanaka and others, 1974). Most of the annual precipitation occurs during storms from October through May; these storms carry a large sediment and associated nutrient load to the river (Greene and others, 1994). The State of Washington has classified the Palouse River as a "Class A" (excellent quality) stream above the confluence with the South Fork Palouse River, and as a "Class B" (good quality) stream below this confluence (Washington State Administrative Code, 1992). The South Fork Palouse River itself is not classified; however, studies conducted by the Washington State Department of Ecology have repeatedly indicated that the South Fork Palouse River has the worst water quality in the State (Pelletier, 1993).

Stream quality in the basin varies with the source of the pollutants. The area is ideally suited for dryland farming of grains and most of the land use is agricultural, although there are some large-scale variations (fig. 1). The Palouse River originates in forested headwaters and transitions into these dryland farming areas. Most of the population and the largest 2 of 11 WWTPs in the basin are in 


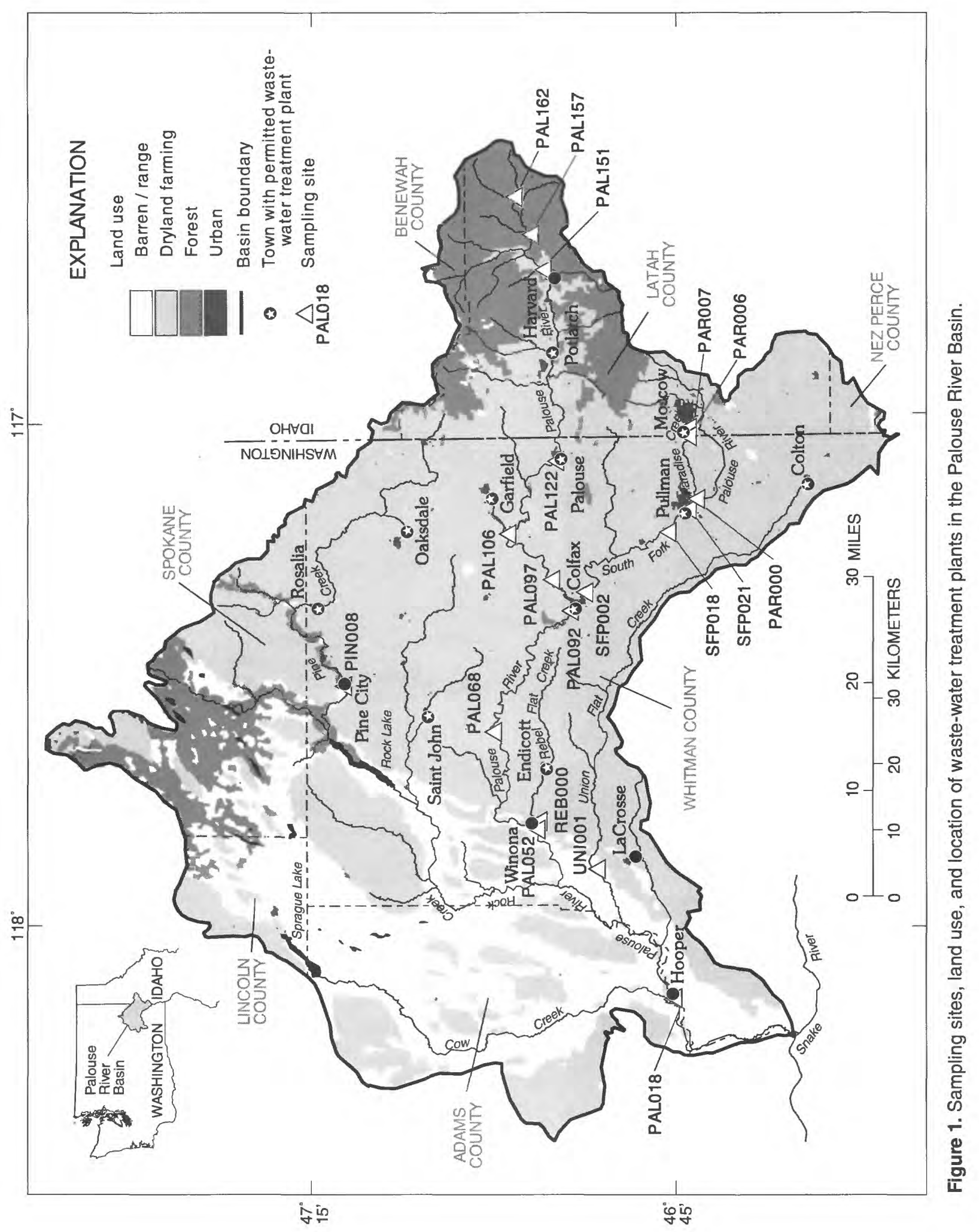


the cities of Moscow and Pullman, both located on the South Fork system, which includes Paradise Creek and the South Fork Palouse River. The South Fork system runs through urban areas, and the water in some reaches of this major tributary of the Palouse River is essentially all WWTP effluent during periods of low streamflow. Downstream from the confluence with the South Fork Palouse River until just upstream from the confluence with Cow Creek, the Palouse River runs through dryland farms and some rangeland. This reach is less affected by WWTP discharges and receives inflow from tributaries draining mostly agricultural land: Rebel Flat, Rock, and Union Flat Creeks all discharge to the Palouse River between about $70 \mathrm{~km}$ and $120 \mathrm{~km}$ downstream from the South Fork confluence. The drainage basins of these tributaries are dominated by dryland farming land use; however, Rebel Flat Creek is affected by a WWTP and Rock Creek is affected locally by cattle grazing and runs mostly through rangeland below Rock Lake. Past Hooper and the mouth of Cow Creek (which joins the Palouse River beyond the most downstream site included in this study), the Palouse River runs through open rangeland and into the Snake River (fig. 1).
Stream quality in the basin also is affected by variation in local hydrologic conditions. During low streamflow, the headwaters and the major tributaries to the Palouse River (including the South Fork Palouse River) generally are gaining flow from the ground-water system, while the rest of the Palouse River is generally losing flow to the ground-water system, with a transitional area in the vicinity of the confluence of the Palouse River and the South Fork Palouse River. Some reaches that in a typical year would be gaining flow may be losing flow during a dry year such as 1994. Due to evapotranspiration, reaches of the Palouse River also undergo varying degrees of diel changes in discharge during low streamflows: during August 1-5, 1994, the changes in streamflow at the downstream site on the South Fork Palouse River averaged about half of the maximum daily flow over a 24-hour period (fig. 2). (It rained in the South Fork Basin during the night of August 4-5.) A similar pattern of diel streamflow variation was observed at the site on the Palouse River above the confluence with the South Fork. Streamflow at the downstream site on the Palouse River was decreasing throughout the study (fig. 2).

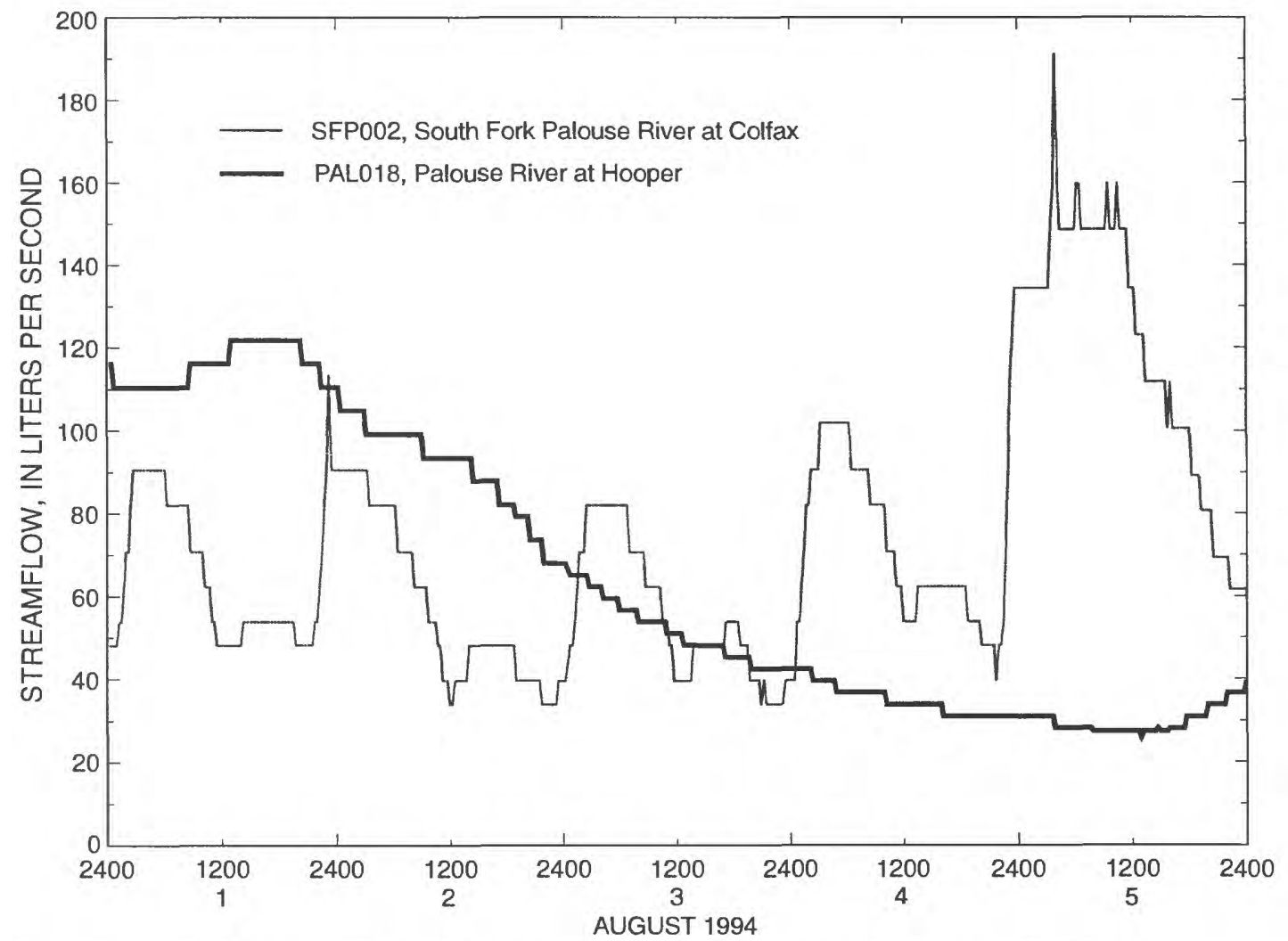

Figure 2. Continuous streamflow at two sites in the Palouse River Basin, August 1-5, 1994. 
The year 1994 was drier than average in the basin, and streamflows were exceptionally low during this investigation: the monthly mean streamflows at the Palouse River at Hooper in July, August, and September for the 1952-1995 water years were $214 \mathrm{~L} / \mathrm{s}$ (liters per second), $89 \mathrm{~L} / \mathrm{s}$, and $111 \mathrm{~L} / \mathrm{s}$, and in the same months in 1994 were $44 \mathrm{~L} / \mathrm{s}, 5.3 \mathrm{~L} / \mathrm{s}$, and $20 \mathrm{~L} / \mathrm{s}$. Therefore, some of the findings of the study may not be applicable or relevant to other, wetter, years.

\section{Study Design and Methods}

Data collection for the study focused on comparing the reaches of the Palouse River system that are dominated by WWTP effects during low streamflows with other parts of the system. The study used the results of several sampling efforts. Synoptic sampling was conducted to assess downstream variations in water-quality conditions and to compare sites influenced to varying degrees by WWTP discharges and agricultural land use. Chlorophyll $a$ was measured at sites throughout the basin in order to identify the physical and chemical factors that control growth of benthic algae in the Palouse River system during low streamflows. A 24-hour study was conducted to determine the extent of diel swings in dissolved oxygen under varying local water-quality conditions and to determine whether nutrient concentrations also vary. Data for the loads calculations came from weekly and monthly site monitoring by the NAWQA program and from ancillary data compiled for NAWQA, some of which was provided by the WWTPs.

\section{$\underline{\text { Site Selection }}$}

Sites were selected that would provide data to assess downstream changes in water quality in the Palouse River system and to compare point and nonpoint pollution sources during low streamflow in the basin. A total of 19 sites was included: 6 sites on the Palouse River above the confluence with the South Fork Palouse River (including 2 sites in the forested headwaters); 6 sites on the South Fork system (which includes the South Fork Palouse River and Paradise Creek); 4 sites on the Palouse River below the confluence with the South Fork; and 3 sites on other major tributaries of the Palouse River (fig. 1, table 1). Many reaches of the Palouse River, and most of the South Fork system, are affected to varying degrees by WWTP effluent, and except for the headwaters sites (PAL162 and PAL157), all of the sites (including the urban sites) are affected to varying degrees by agricultural activities. The sites on tributaries (and in particular, Pine Creek, which is located upstream from Rock Lake) were chosen to represent stream-quality conditions in similar (dryland farming) land uses, not to represent inflow to the Palouse River. Because Rock Creek and Cow Creek drain rangeland, no sites were located on these tributaries.

The low-flow synoptic study was done at all 19 sites to assess water-quality conditions along the Palouse River and the South Fork system, including the added inflow from other tributaries below the South Fork. The 24-hour study was done at five of the sites (PAL097, SFP018, SFP002, PAL092, and PAL018) to determine the magnitude of diel fluctuations in nutrient and dissolved oxygen concentrations. PAL097 and SFP002 (fig. 1) provided data for comparing streams dominated by agricultural and urban (WWTP) effects; SFP018 and SFP002 on the South Fork Palouse River about $4 \mathrm{~km}$ past the Pullman WWTP and $26 \mathrm{~km}$ further downstream provided data for assessment of downstream effects; PAL092 represented conditions on the Palouse River just below the Colfax WWTP and the confluence with the South Fork; and PAL018, $120 \mathrm{~km}$ downstream from the confluence, represented the combined effects of all land uses and pollution sources after instream mitigating effects.

\section{Water-Quality Sampling}

For the low-flow nutrient synoptic sampling, measurements of streamflow, water temperature, $\mathrm{pH}$, dissolved oxygen concentration, specific conductance, and alkalinity were made at the stream centroid at all 19 sites between 5:00 a.m. and 9:00 a.m. during the first week of August 1994. Depth- and width-integrated water chemistry samples were collected and processed at the same time; sampling methods are described in Shelton, 1994. A 24-hour composite sample provided by the Pullman WWTP also was analyzed. Samples were analyzed at the U.S. Geological Survey's National Water Quality Laboratory in Denver, Colo. Samples for "dissolved" constituents were filtered through a $0.45 \mu \mathrm{m}$ (micrometer, or micron) filter; samples for "total" constituents were unfiltered. Concentrations measured below the analytical detection limit for any constituent are indicated as "less-than" values (for example, $<0.01 \mathrm{mg} / \mathrm{L}$ ) in the data tables (Appendices A and B) and were assigned values of half the detection limit $(0.005 \mathrm{mg} / \mathrm{L}$ for the same example) for interpretive analyses.

Laboratory analyses for nutrients (including dissolved nitrate, dissolved nitrite, dissolved ammonia, dissolved and total organic nitrogen, total phosphorus, and dissolved orthophosphate), dissolved organic carbon, 


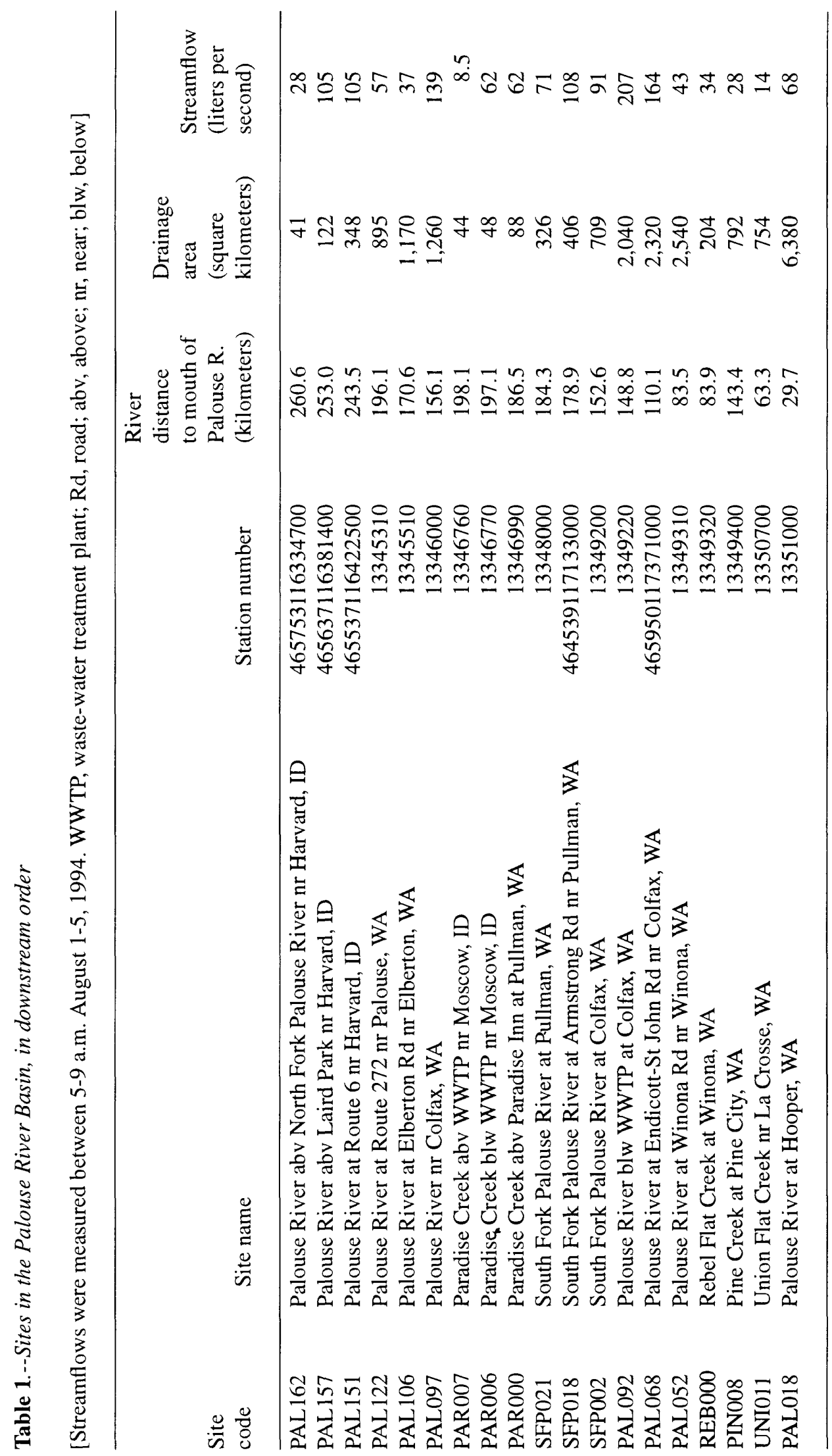


common ions (chloride, fluoride, sulfate, silica, sodium, calcium, potassium, magnesium, iron, and manganese), and dissolved solids were made for all of the samples. (The common ions sample for PAL162 was incomplete, and only chloride, fluoride, and sulfate were analyzed.) Turbidity was measured at 13 of the sites.

Dissolved oxygen concentration, water temperature, $\mathrm{pH}$, specific conductance, and alkalinity were measured every 3 hours during the same 24-hour period at five of the sites (PAL097, PAL092, PAL018, SFP018, and SFP002) on August 2-3, 1994. Samples for dissolved solids, nutrients (see above) and common ions (see above) were collected every 6 hours. Streamflow was measured at around $6 \mathrm{p} . \mathrm{m}$. and again at around 6 a.m.; two of the sites (PAL018 and SFP002) have continuous stage measurements.

Quality analysis and control data are collected as part of the NAWQA program, and the data, including frequent analyses of replicate nutrient samples and blank dissolved organic carbon and common ions samples, are monitored during regular NAWQA sampling activities (Shelton, 1994). No additional quality analysis and control data for water chemistry were collected during the synoptic sampling and 24-hour study conducted for this investigation.

\section{Measuring Growth of Benthic Algae and Identifying Controlling Variables}

Several methods may be used to determine which resources limit the growth of attached benthic algae in a stream: methods include whole-stream enrichment (Gregory, 1980); nutrient-diffusing substrata (Fairchild and others, 1985; Pringle, 1987; Munn and others, 1989); correlation techniques (Kilkus and others, 1975; Munn and others, 1989); and ratios of inorganic nitrogen to orthophosphate, or N:P ratios (Welch, 1980). In this study, a correlation and regression approach was used. In this report, the phrase "growth of benthic algae" refers to accrual of benthic algae, which is the combination of benthic algae colonization and growth, which was measured successfully at 16 of the 19 attempted sites that were located in various combinations of land uses including forested areas, urban areas, dryland farming, and rangeland. Many sites were affected, to varying degrees, by WWTP discharges (fig. 1). The photosynthetic pigment chlorophyll $a$ was used as the indicator of growth of benthic algae.
The production of chlorophyll $a$ was measured using artificial substrates constructed from $25 \mathrm{~cm}^{2}$ unglazed ceramic tiles that were secured to concrete bricks using water-resistent marine cement. These artificial substrates were placed in runs with similar depths and current velocities to the extent that similar conditions were possible. The natural substrate at most of the sites was gravel and cobble although a few sites had gravel and silt substrates. Replicate artificial substrates were positioned at each of the sites in mid-July 1994 and were left for an 8-week colonization period. After 8 weeks, three tiles from the artificial substrates at each of the sites were retrieved and separated from the concrete bricks. Colonization was successful at 16 of the sites (the tiles at PAL122 were vandalized, and the reaches where the artificial substrates were located went dry at PAL097 and UNI011). The algae were scraped from each tile and filtered onto separate $0.2 \mu \mathrm{m}$ Gelman glass fiber filters, wrapped in foil, and frozen on dry ice. At the laboratory, samples were analyzed for chlorophyll $a$ concentrations using the fluorometric method (American Public Health Association, 1985).

The following physical measurements were made when the tiles were removed: depth of water, in centimeters $(\mathrm{cm})$; water velocity, in meters per second $(\mathrm{m} / \mathrm{s})$ at six tenths of the total depth; water temperature, in degrees Celsius (' $\mathrm{C}$ ); light just below the water surface, in lux units; and solar energy, in kilocalories per tenth of square meter per day $\left(\mathrm{kcal} / 0.1 \mathrm{~m}^{2} / \mathrm{d}\right)$, calculated for the 8 -week colonization period. Additional measurements were made during the synoptic study described above.

Normality plots indicated that chlorophyll $a$, nutrients, and some physical variables had a bimodal distribution. This distribution was probably due to differences in water quality and growth of benthic algae among sites in the South Fork system and sites in other parts of the basin; therefore, data for the main channel Palouse River and data for the South Fork system were analyzed separately. Although this separation of data resulted in two unimodal distributions, normality plots indicated that some variables were not normally distributed. Therefore, in order to satisfy the assumptions of parametric statistics, a $\log _{10}$ transformation was applied to the non-normal variables. A Pearson correlation coefficient matrix was constructed with corresponding correlation coefficients $(r)$ and associated probability $(P)$ values.

Results from the correlation matrix were used to construct multiple regression models in which chlorophyll $a$ was the dependent variable. The independent physical and chemical variables selected for use in the model fulfilled three criteria: (1) the independent variable was correlated 
with chlorophyll $a$ at the $P=<0.05$ level; (2) to avoid collinearity, the independent variable was not correlated with any other independent variable included in the model; and (3) each independent variable had a significant $(P=<0.05)$ influence on the model. Regression models were constructed using various combinations of sites to determine how the variables influence growth of benthic algae in different land uses.

\section{Calculation of Nutrient Loads}

A statistical model (Cohn and others, 1992) was used to estimate annual loads of total nitrogen and phosphorus at PAL018 (fig. 1), the only site in the basin for which the long-term flow and water-quality data needed for the model input are available (Greene and others, 1994). The model uses multiple regression analyses to relate $\log _{10}$-transformed concentrations of total nitrogen and phosphorus to daily mean streamflows and time. The regression equation was used to estimate concentrations of total nitrogen and phosphorus at times when no samples were collected. Constituent loads were then computed on a daily basis by multiplying estimated concentrations by daily mean streamflow, and the daily loads were summed to determine annual loads. Annual loads at PAL018 were used to estimate annual export of nitrogen and phosphorus in surface-water flow from the basin.

Loads of total nitrogen and phosphorus were estimated for each month of the 1994 water year at SFP002 (fig. 1) and for the discharges of the Moscow and Pullman WWTPs. For SFP002, loads were computed as the product of the concentration of total nitrogen or phosphorus and the daily mean water discharge. Daily concentrations of total nitrogen and phosphorus were estimated by linear interpolation between concentrations in samples, which were collected at approximately monthly intervals. The daily loads were summed to determine monthly loads.

Mean monthly effluent discharges, which were available for both the Moscow and Pullman WWTPs, were multiplied by concentrations of total nitrogen and phosphorus to estimate monthly loads. Concentrations of total nitrogen and phosphorus in effluent from the Moscow WWTP were determined monthly, and the concentration of total nitrogen or phosphorus in a single sample collected within a given month was used to represent the entire month. Fewer data were available for the Pullman WWTP where the average concentrations of total nitrogen and phosphorus in three samples were used to represent typical concentrations. The single average concentration of total nitrogen or phosphorus was used in the load computation.

\section{INPUTS AND EXPORT OF NUTRIENTS}

Local pollution sources in the Palouse River Basin include a range of permitted WWTP discharges, some limited logging and historic mining practices in the headwaters, fertilizers, and cattle grazing, which is common in the basin and known to occur along the stream reaches above PIN008, PAL106, and PAL018 (fig. 1). The two largest WWTPs in the basin are in the cities of Moscow and Pullman, both located on the South Fork system. The permitted discharges are about $130 \mathrm{~L} / \mathrm{s}$ from the Moscow WWTP and $190 \mathrm{~L} / \mathrm{s}$ from the Pullman WWTP (Greene and others, 1994). The WWTPs in Colfax and eight smaller towns in the basin are permitted to discharge less than $44 \mathrm{~L} / \mathrm{s}$. WWTP effluent directly contributes large quantities of nutrients to the river. Ninety-one percent of the total nitrogen loading and 69 percent of the phosphorus loading from WWTPs to the entire Palouse River system are to the South Fork system, mostly from the Pullman and Moscow WWTPs (Greene and others, 1994). The effects of WWTP loading are most pronounced during low streamflow in the South Fork system; one result is dense mats of aquatic vegetation along most of this reach of the river (Joy, 1987).

Although effluent from WWTPs is the primary source of nutrients to the South Fork system during low streamflows, it represents only about 4 percent of the total nitrogen input and 7 percent of the total phosphorus input to the South Fork Palouse River drainage basin (table 2). More than 98 percent of the total nitrogen and phosphorus inputs to the entire Palouse River drainage basin are from nonpoint sources. Fertilizers used on cropland are the largest single source, making up about 83 percent of the total nitrogen input and 80 percent of the total phosphorus input. Nutrient inputs to the drainage basin do not represent inputs to the river, however. In contrast to WWTP effluent, much of the input from fertilizers, atmospheric deposition, and livestock never reaches the river. The nutrients from nonpoint sources that reach the river during low streamflows are mostly from shallow ground water, which has higher nitrate concentrations than deep ground water in the basin (Jones and Wagner, 1995) but still probably constitutes only a minor input of nutrients to the river. Only about 5 percent of the total nitrogen and 4 percent of the total phosphorus inputs to the basin during 1 year are exported in surface-water discharge during an average flow year (Greene and others, 1994). 
Table 2.--Annual inputs of nitrogen and phosphorus to parts of the Palouse River Basin

[Inputs are to drainage areas contributing to sampling sites listed. PAL018 represents most of the Palouse River drainage basin. PAL092 represents most of the Palouse River drainage basin above the confluence with the South Fork Palouse River. SPF002 represents the drainage basin of the South Fork Palouse River. Abbreviations for sampling sites are given in table 1. WWTP, waste-water treatment plant; --, no data]

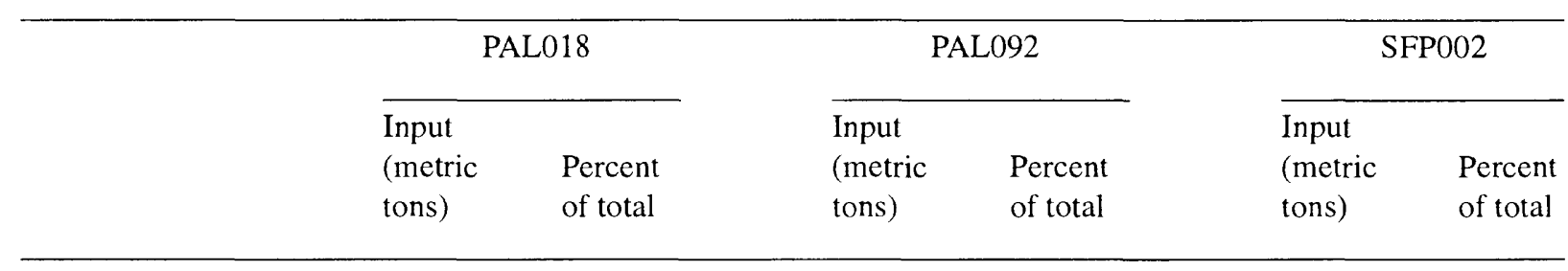

Nitrogen

$\begin{array}{lrrrrrr}\text { Fertilizer }^{1} & 18,400 & 83.4 & 2,390 & 74.8 & 2,520 & 82.4 \\ \text { Wet deposition }^{2} & 1,840 & 8.4 & 466 & 14.6 & 227 & 7.4 \\ \text { WWTPs }^{3} & 138 & 0.6 & 6.6 & 0.2 & 125 & 4.1 \\ \text { Livestock }^{4} & 1,680 & 7.6 & 332 & 10.4 & 186 & 6.1\end{array}$

Phosphorus

$\begin{array}{lcccccc}\text { Fertilizer }^{1} & 2,410 & 80.4 & 314 & 73.0 & 330 & 78.7 \\ \text { Wet deposition }^{2} & -- & -- & -- & -- & -- & -- \\ \text { WWTPs }^{3} & 42.4 & 1.4 & 8.6 & 2.0 & 29.1 & 6.9 \\ \text { Livestock }^{4} & 544 & 18.2 & 108 & 25.0 & 60.5 & 14.4\end{array}$

${ }^{1}$ Application amounts were estimated by multiplying the area of cropland in each drainage basin times average annual rates of nitrogen and phosphorus applications to cropland in Whitman County. Crop areas were obtained from 1972 Geographic Information Retrieval and Analysis System (GIRAS) digital land-use land-cover data (Anderson and others, 1976). Average annual application rates of nitrogen and phosphorus represent 1992 data (U.S. Department of Commerce, 1994).

${ }^{2}$ Computed as the product of the concentration of nitrogen in rainfall times the annual volume of rainfall in the drainage basin. The concentration of nitrogen in precipitation is the sum of the precipitation-weighted mean concentration of nitrate and ammonia in samples collected 1985-91 at Pullman, Washington (National Atmospheric Deposition Program, 1985-91).

${ }^{3}$ All inputs from WWTPs are from Greene and others (1994), excluding inputs from the Pullman and Moscow WWTPs, which are described in the methods section of this report.

${ }^{4}$ Estimates are based on 1987 animal population data (R.B. Alexander, U.S. Geological Survey, written commun., 1992).

During periods of high aquatic plant productivity and low streamflows, a large percentage of the inorganic nitrogen discharged from the Moscow and Pullman WWTPs is removed from the South Fork system. This is evident when comparing concentrations of inorganic nitrogen in the samples collected during the 24-hour study at SFP018, located about $4 \mathrm{~km}$ downstream from the Pullman WWTP, with concentrations in the samples collected at SFP002, $30 \mathrm{~km}$ downstream from the Pullman WWTP (Appendix B). Orthophosphate concentrations did not decrease similarly along the same river reach.
Monthly mean discharges of total nitrogen, total phosphorus, and water from October 1993 through September 1994 (the 1994 water year) at the South Fork Palouse River at SFP002 are shown along with the corresponding combined discharges from the Moscow and Pullman WWTPs in fig. 3. In July 1994, the discharge of total nitrogen at SFP002 was only about 6.5 percent of the combined discharges from the two WWTPs. Discharges of total phosphorus and water at SFP002 were about 35 and 72 percent of the combined discharges from the two 

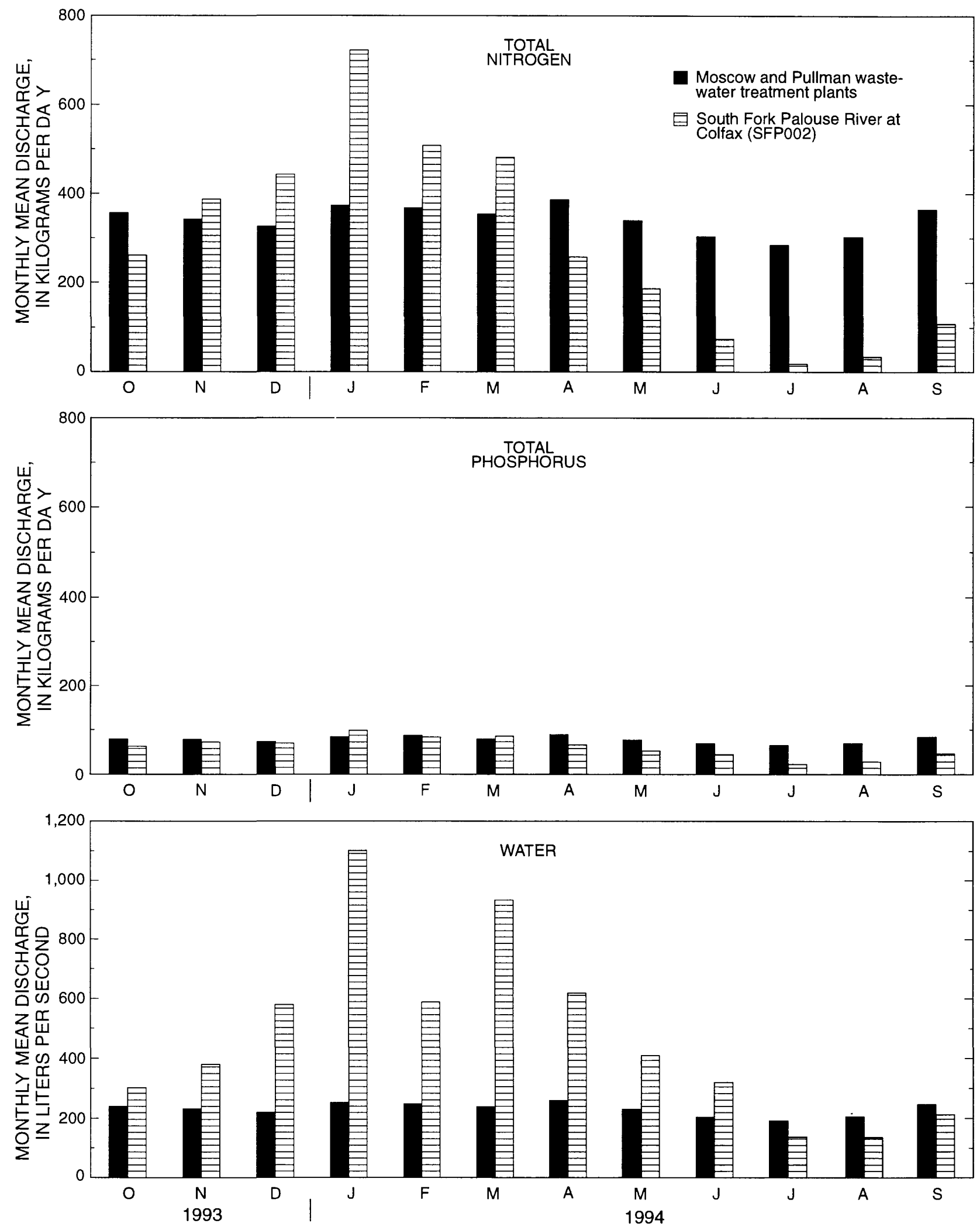

Figure 3. Monthly mean discharges of nitrogen, phosphorus, and water from the Moscow and Pullman waste-water treatment plants (WWTPs), and at the South Fork Palouse River at Colfax. 
WWTPs during the same month. According to these estimates for the month of July, nitrogen and phosphorus contained in the WWTP discharges are removed from the South Fork Palouse River at a molar ratio of about 14:1, which is similar to the $16: 1$ ratio of nitrogen and phosphorus theoretically used by plants. During the 24-hour study in August, however, the ratio was 29:1, indicating that another process was contributing to nitrogen removal in the reach.

Monthly mean discharges of total nitrogen at SFP002 were less than the combined monthly mean discharges from the two WWTPs for all months except November through March, when there is much less uptake of inorganic nitrogen by plants and contributions of total nitrogen from nonpoint sources, especially overland runoff, become significant (Greene and others, 1994). However, because the 1994 water year was drier than average (the annual mean streamflow at PAL018 was 23 percent of the mean annual flow), contributions of total nitrogen to the Palouse River from nonpoint sources were less than average during 1994.

\section{NUTRIENTS AND STREAM QUALITY DURING LOW STREAMFLOW}

During low streamflows, total nitrogen and total phosphorus loads in the Palouse River system are composed mostly of dissolved rather than suspended components. (PAL018, the downstream site, has larger sediment concentrations and more suspended material in the water column than the rest of the sites, and is the exception.) Total dissolved nitrogen is composed of both organic and inorganic nitrogen species. Dissolved phosphorus is composed mostly of orthophosphate, an inorganic species. Nitrate, nitrite, ammonia, and orthophosphate are dissolved inorganic nutrient species that are needed by plants for growth and are available for uptake by aquatic plants; organic forms of nitrogen are not available for direct use by aquatic plants.

At most sites on the main channel Palouse River, the dissolved nitrogen is mostly organic (fig. 4). (Again, PAL018 is the exception, with equal portions of organic and inorganic dissolved nitrogen.) In contrast, dissolved

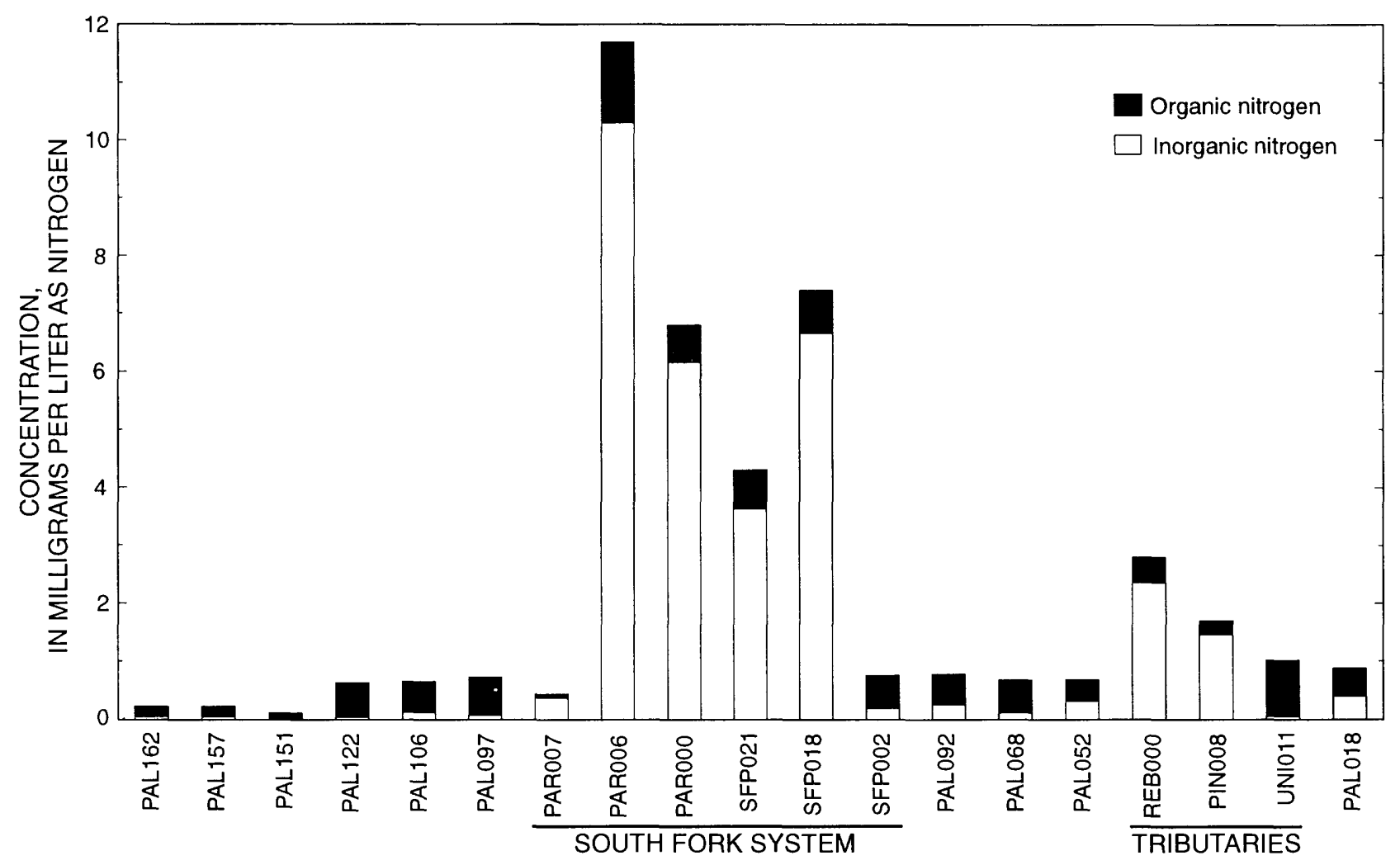

Figure 4. Total dissolved organic and inorganic nitrogen concentrations in synoptic samples collected August 1-5, 1994 , at sites in the Palouse River Basin. Inorganic nitrogen is nitrate plus nitrite plus ammonia. Sites are listed in table 1. 
nitrogen at most of the sites on the South Fork system is composed of mostly inorganic nitrogen, which is contributed in large proportions by the WWTPs: more than 95 percent of the total dissolved nitrogen in the 24-hour composite sample of effluent from the Pullman WWTP was nitrate plus nitrite.

\section{Spatial Variations}

Concentrations of inorganic nutrients measured at all 19 sites during the synoptic sampling are shown in figure 5; the data are included in Appendix A. Nutrient concentrations in the Palouse River from the headwaters to the downstream site PAL018 (river kilometer 30) were generally lower than concentrations in the urban, WWTPaffected South Fork system (which includes the South Fork Palouse River and Paradise Creek). The WWTP inputs to the South Fork system make large quantities of nutrients available for plant growth, and aquatic plants are prolific in this reach. Because aquatic plants use much larger amounts of inorganic nitrogen than orthophosphate, and because denitrification probably removes additional inorganic nitrogen under extreme low dissolved oxygen conditions, the removal of inorganic nitrogen in the South Fork system was more complete than the removal of the orthophosphate, and orthophosphate concentrations remained high far downstream (fig. 5); this is discussed
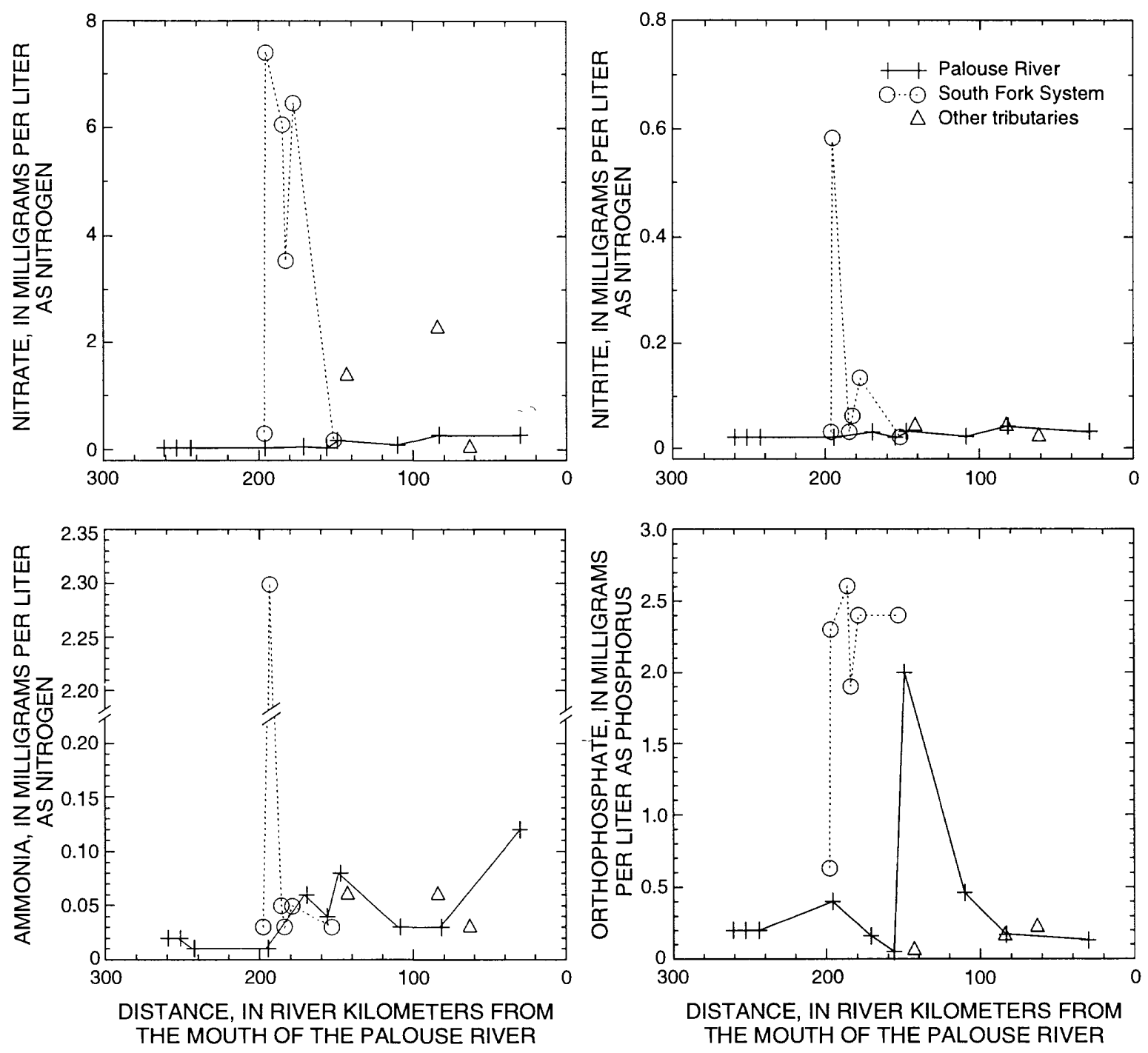

Figure 5. Concentrations of dissolved inorganic nutrients at sites in the Palouse River Basin, August 1-5, 1994. Sites are listed in downstream order in table 1. 
further in the "Factors Controlling Growth of Benthic Algae" and "Factors Affecting Nutrient Concentrations" sections of this report. Inorganic nitrogen concentrations were low at the downstream site SFP002 (river kilometer 153) on the South Fork system, and from PAL092 (river kilometer 149) to PAL052 (river kilometer 84) below the confluence of the Palouse River and the South Fork there were no additional surface-water sources of nutrients during the period of the study, limiting the supply of inorganic nitrogen available to be used by plants to remove the remaining orthophosphate.

\section{Chloride as a Possible Indicator of Waste-Water Treatment Plant Effluent}

In addition to nutrients, many other common constituents are contributed by WWTPs in large quantities to the receiving streams. Concentrations of chloride, a stable dissolved constituent, measured during the synoptic sampling are shown in figure 6; chloride increases slightly between PAL151 (river kilometer 244) and PAL122 (river kilometer 196) due to the Potlatch and Palouse WWTPs, and then increases by an order of magnitude at PAL092 (river kilometer 149) due to the combined inflows of the WWTP-affected South Fork and the Colfax WWTP. The decrease in chloride concentrations further downstream indicates that the combined WWTP effluent from all sources upstream from PAL092, including the Colfax, Pullman, and Moscow WWTPs (fig. 1), probably was diluted by recharge from the ground-water system. This

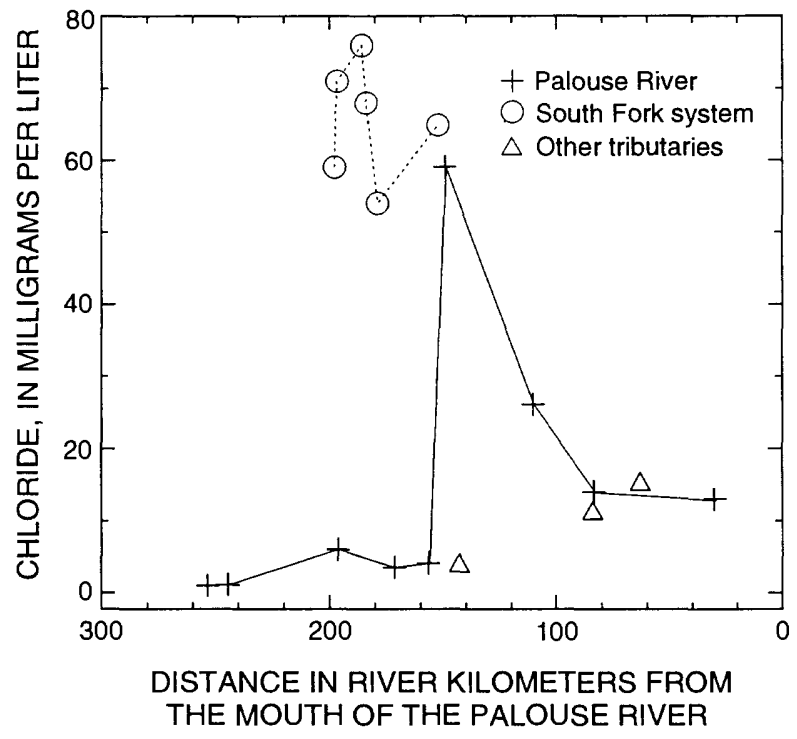

Figure 6. Concentrations of chloride at sites in the Palouse River Basin, August 1-5, 1994. Sites are listed in downstream order in table 1. pattern is similar to that observed for orthophosphate (fig. 5), which may be lost to both plant uptake and sorption to sediments in addition to dilution and ground-water exchange. The loss of WWTP effluent together with the natural river water originating upstream from PAL092, from the surface-water system through the losing reaches of the Palouse River past PAL052, is discussed further in the "Factors Affecting Nutrient Concentrations" section of this report.

\section{Dissolved Oxygen Concentrations and $\mathbf{p H}$}

Dissolved oxygen concentrations and $\mathrm{pH}$ were measured once between 5 and 9 a.m. at each of the 19 sites during the synoptic sampling (Appendix A). Only 3 of the 10 sites on the Palouse River met Washington State's minimum standards for dissolved oxygen: $8.0 \mathrm{mg} / \mathrm{L}$ for a "Class A" stream, which applies to sites on the Palouse River above the confluence with the South Fork, and $6.5 \mathrm{mg} / \mathrm{L}$ for a "Class B" stream, which applies to sites below the confluence (Washington State Administrative Code, 1992). PAL157 (river kilometer 253) and PAL106 (river kilometer 171) met the "Class A" standard and PAL052 (river kilometer 84) met the "Class B" standard. Six of the 10 sites on the Palouse River met the State's standard for maximum $\mathrm{pH}$ (8.5 units for both "Class A" and "Class B" streams) during the synoptic sampling (Appendix A).

\section{Nutrients in the Palouse River}

Water in the headwaters of the Palouse River had only trace amounts of inorganic nitrogen and orthophosphate, and the only notable change in nutrient concentrations downstream to PAL097 (river kilometer 156), above the confluence with the South Fork Palouse River, was a small increase in orthophosphate at PAL106 (river kilometer 171) and a subsequent decrease (fig. 5). During low streamflows, the source of nutrients to the Palouse River upstream from the confluence with the South Fork is probably small WWTPs and possibly local cattle-grazing. At PAL092 (river kilometer 149) below the confluence, there was a large increase in orthophosphate resulting from the WWTP-affected inflow from the South Fork system and effluent from the Colfax WWTP. The WWTP inputs to the Palouse River at and below the confluence are of a considerably greater magnitude than the WWTP inputs to the reach upstream from the confluence. Further downstream, the river receives inflow from other major tributaries between PAL052 (river kilometer 84) and PAL018 (river kilometer 30) (fig. 1). 
Concentrations of nitrate and nitrite in the Palouse River were relatively constant downstream below the confluence with the South Fork. Ammonia and orthophosphate concentrations decreased from PAL092 (river kilometer 149) to PAL068 (river kilometer 110) (fig. 5); from PAL068 to PAL052 (river kilometer 84), ammonia concentrations remained about the same and orthophosphate concentrations continued to decrease, approaching the concentrations observed above the South Fork (fig. 5). From PAL052 to PAL018 (river kilometer 30), orthophosphate decreased slightly, but ammonia increased, possibly due to direct contributions from cattle-grazing sources and additional conversion of organic nitrogen (also possibly from cattle) to ammonia along this reach.

Nitrate concentrations were higher in the agricultural tributaries REB000 (river kilometer 84) and PIN008 (river kilometer 143) than in the Palouse River; nitrate was not detected at UNI011 (river kilometer 63) (fig. 5). Nitrite and ammonia concentrations were generally about the same in these tributaries and in the Palouse River. Orthophosphate concentrations were lower than in the reach from PAL092 (river kilometer 149) to PAL068 (river kilometer 110) but were similar to concentrations in the Palouse River at PAL052 (river kilometer 84) and PAL018 (river kilometer 30 ).

\section{Nutrients in the South Fork System}

The site below the Moscow WWTP, PAR006 (river kilometer 197), had the highest concentrations of nitrate $(7.4 \mathrm{mg} / \mathrm{L})$, nitrite $(0.57 \mathrm{mg} / \mathrm{L})$, and ammonia $(2.3 \mathrm{mg} / \mathrm{L})$ observed in the basin, and concentrations of all of the nutrient species were higher at most of the sites in the South Fork system than in the Palouse River (fig. 5); Washington State's acute toxicity standard for ammonia $(0.15 \mathrm{mg} / \mathrm{L}$ for the $\mathrm{pH}$ and water temperature measured at the site; Washington State Administrative Code, 1992) was exceeded at PAR006. The sum of nitrate, nitrite, and ammonia concentrations decreases sharply from $10.3 \mathrm{mg} / \mathrm{L}$ at PAR006 to $6.15 \mathrm{mg} / \mathrm{L}$ at PAR000 (10 kilometers downstream), but the orthophosphate concentration actually was higher at PAR000 $(2.6 \mathrm{mg} / \mathrm{L})$ than at PAR006 (2.3 $\mathrm{mg} / \mathrm{L})$ : this may have been due to solubilizing of phosphorus from the bed sediments. The decrease in nitrogen was probably due to uptake by aquatic plants and denitrification under low dissolved oxygen conditions in the reach; this is discussed further in the "Factors Affecting Nutrient Concentrations" section of this report. Nitrate continued to decrease along the South Fork until concentrations of both nitrate and nitrite increased again at SFP018 (river kilometer 179) due to effluent from the Pullman WWTP, although there was less nitrate at SFP018 than at PAR006. There was only a small increase in ammonia concentration at SFP018 because the Pullman WWTP effluent is mechanically oxygenated. Due to continued uptake and denitrification along the reach downstream from SFP018, nitrate, nitrite, and ammonia concentrations at SFP002 (river kilometer 153, just above the confluence with the Palouse River) were reduced to levels as low as those measured at sites on the upper Palouse River (fig. 5). Concentrations of orthophosphate, however, remained high from PAR006 to SFP002.

Concentrations of silica also decreased downstream in the South Fork system, from $70 \mathrm{mg} / \mathrm{L}$ at PAR006 (river kilometer 197), to $42 \mathrm{mg} / \mathrm{L}$ at SFP018 (river kilometer 179 ), to only $9.3 \mathrm{mg} / \mathrm{L}$ at SFP002 (river kilometer 153 ). (The concentration at PAL097 (river kilometer 156) was $16 \mathrm{mg} / \mathrm{L}$.) Silica is required for growth by a group of algae called diatoms, and the decrease in silica in this river reach was most likely due to assimilation by diatoms.

\section{Temporal Variations}

Nutrient concentrations observed over the 24-hour period changed due to some combination of the diel variations in plant productivity, streamflow conditions, and WWTP inputs. Two sites on the South Fork Palouse River (SFP018 and SFP002) and three sites on the Palouse River (PAL 097, PAL092, and PAL018) were included in the 24-hour study (see fig. 1). Selected results from the 24-hour study are shown in Appendix B. The changes in nutrient concentrations are manifested differently at each site but are especially evident at the three WWTP-affected sites (SFP018, SFP002, and PAL092), which have large amounts of nutrients available and extensive aquatic plant growth.

Changes in streamflow were observed at the two continuous gaging sites, SFP002 and PAL018. As shown in figure 2, streamflow was continuously decreasing at PAL018, but there was a slightly bimodal diel variation in streamflow at SFP018. The primary diel variation (a decrease of about half the maximum daily flow, similar to the change observed at PAL097 during the 24-hour study) was most likely a result of evapotranspiration effects, and the small secondary diel variation (an increase of 10-15 percent of the maximum daily flow, observed during the daily low natural flows) may have been due to WWTP discharges. 
Changes in the 24-hour concentration data due to WWTP discharges were difficult to identify. Chloride concentrations varied about 10 percent over the 24-hour period at SFP018 and PAL092, the sites just downstream from the Pullman and Colfax WWTPs, indicating that there may have been some change in WWTP discharges. However, the other common ion concentrations (excluding iron and manganese) remained essentially unchanged at SFP018, but varied at PAL092, where the lowest chloride concentration corresponded with the highest nitrate concentration, rather than the lowest (Appendix B). At PAL092, iron and manganese concentrations varied by two orders of magnitude during the 24-hour period, possibly due to the changing dissolved oxygen conditions at the sampling site rather than changes in streamflow and discharges from the Colfax WWTP.

\section{Nutrients in the Palouse River}

The 24-hour changes in nitrate concentrations at the three sites on the Palouse River were smaller than those observed at sites on the South Fork system. Among these three sites, nitrate changed most at PAL092, the site below the Colfax WWTP, where the nitrate concentration was highest at 1 a.m. and lowest at 12:30 p.m. At PAL097, above the South Fork system, nitrate was detected in only one sample, at 6 p.m. Nitrate at PAL018, the most downstream site, was lowest at 11:30 p.m. and highest at 11:30 a.m., although the change was small. Nitrite concentrations at each site remained about the same during the 24-hour study.

Some changes in ammonia concentrations were observed at these three sites, although concentrations were small. At PAL018 (the site with the largest change) the ammonia concentration ranged from $0.06 \mathrm{mg} / \mathrm{L}$ at $5: 30$ p.m. to $0.12 \mathrm{mg} / \mathrm{L}$ at 5:30 a.m, when water temperature and $\mathrm{pH}$ had the lowest observed values at that site. Water temperature greater than $25^{\circ} \mathrm{C}$ and $\mathrm{pH}$ greater than 8.4 for the same observation indicate conditions under which ammonification, or volatilization of ammonia, may occur (Bowie and others, 1985); such conditions were observed from about noon to 9 p.m. at all three sites during the 24-hour study (Appendix B).

At PAL092, below the Colfax WWTP, orthophosphate concentrations were lowest at 6:30 p.m. and highest at 6:30 a.m., similar to the pattern of 24-hour changes at the WWTP-affected South Fork sites. Orthophosphate changed little at PAL097 and at PAL018, where concentrations were an order of magnitude lower than at PAL092.

\section{Nutrients in the South Fork System}

At the two 24-hour sites on the South Fork Palouse River, the lowest observed concentrations for any of the nutrients were observed late in the afternoon, between 5 and 6 p.m., and the highest concentrations were between 5 a.m. and noon. There were larger 24-hour changes in concentrations of nitrate and nitrite at SFP01 8 than at SFP002. Orthophosphate concentrations, however, changed over the 24-hour period at SFP002, the downstream site, but not at SFP018, just below the Pullman WWTP, where orthophosphate concentrations remained constant throughout the 24-hour period (see Appendix B).

Concentrations of ammonia were between $0.03 \mathrm{mg} / \mathrm{L}$ and $0.05 \mathrm{mg} / \mathrm{L}$ at all times during the 24-hour period at both sites. Water temperature and $\mathrm{pH}$ were high enough to indicate possible ammonification from 2 to $8 \mathrm{p} . \mathrm{m}$. at SFP002, but only at 6 p.m. at SFP018; however, compared to the magnitude of the loss of nitrate and nitrate from SFP018 to SFP002, the amount of nitrogen lost from the reach by ammonification probably was negligible.

The concentrations of nitrate and nitrite at SFP002 were much lower than at SFP018 at all times of the day, but the concentrations of orthophosphate were lower at SFP002 at 5 to 6 p.m. and 11 p.m. to midnight, and equivalent to SFP018 at 5 to 6 a.m. and 11 a.m. to noon. This is probably because inorganic nitrogen is consumed at a much higher rate than orthophosphate is consumed by the aquatic plants in the reach; there also may have been a downstream lag in daytime productivity.

\section{Dissolved Oxygen Concentrations and pH}

Large changes in dissolved oxygen (DO) concentrations were observed at the five 24-hour study sites in the basin. Changes in DO occur primarily because aquatic plants produce more DO than they consume during the daytime, increasing concentrations and plants continue to consume DO but do not produce DO at night, decreasing concentrations and resulting in a diel swing. The three 24-hour sites affected by WWTPs had the largest diel swings, the lowest nighttime concentrations, and the most supersaturated afternoon concentrations (fig. 7). The magnitude of the change in DO at a single site ranged from $4.6 \mathrm{mg} / \mathrm{L}$ to $14.7 \mathrm{mg} / \mathrm{L}$ over the 24 -hour period. The $\mathrm{min}$ imum DO concentration standard of $6.5 \mathrm{mg} / \mathrm{L}$ for a "Class B" stream (Washington State Administrative Code, 1992) was not met for more than 6 hours of the 24 -hour period at all five of the sites. The lowest DO concentrations were measured at SFP002 (1.1 mg/L at 2 a.m. $)$ and at SFP018 


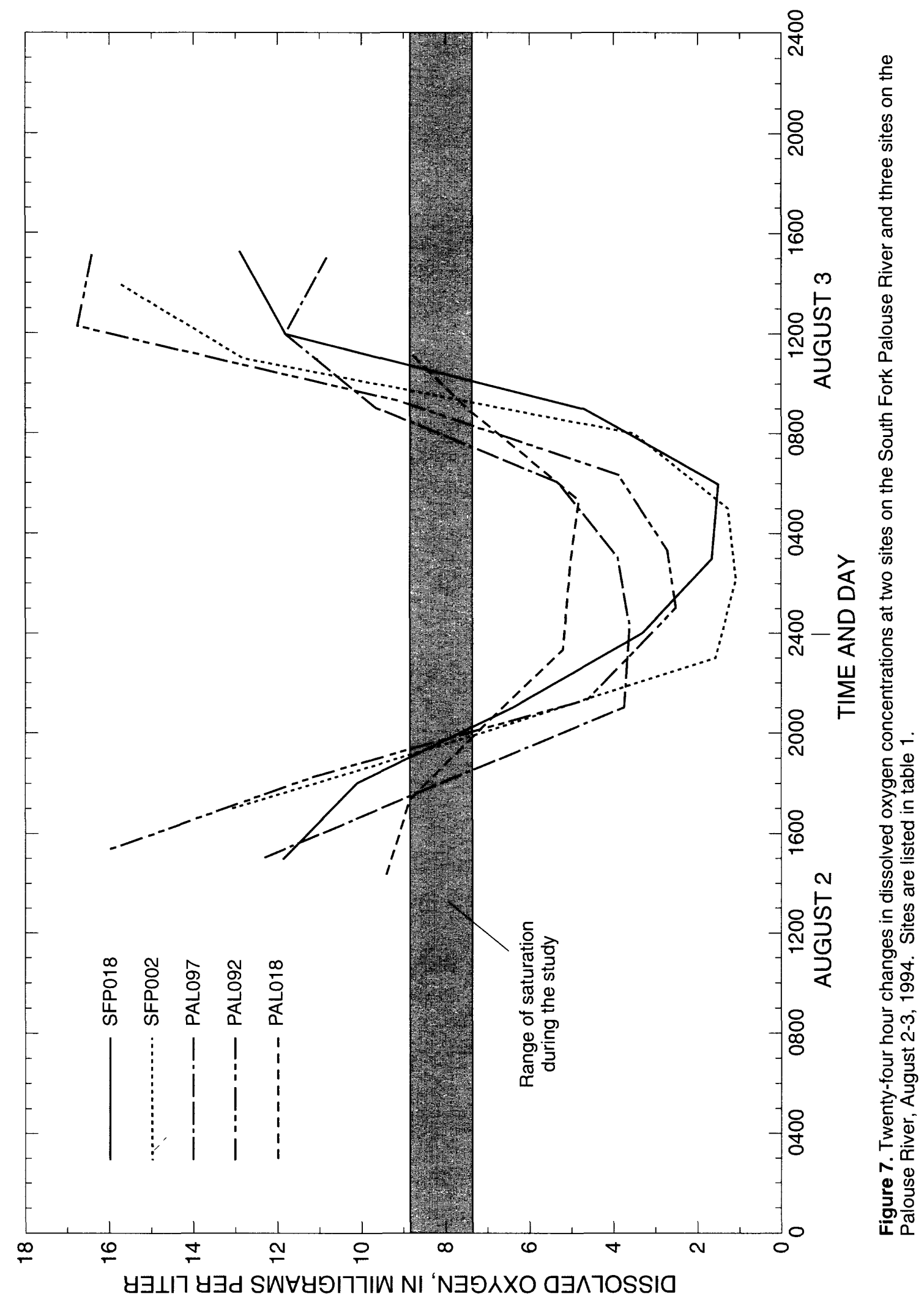


$(1.5 \mathrm{mg} / \mathrm{L}$ at 6 a.m.), the two sites on the South Fork Palouse River; and the highest observed concentration was at PAL092 (16.7 $\mathrm{mg} / \mathrm{L}$ at 12:30 p.m.), the site below the Colfax WWTP.

The magnitudes of the changes in 24-hour DO concentrations at the WWTP-affected sites were $11.4 \mathrm{mg} / \mathrm{L}$ at SFP018, $14.7 \mathrm{mg} / \mathrm{L}$ at SFP002, and $14.2 \mathrm{mg} / \mathrm{L}$ at PAL092. The smallest DO swing was at PAL018, the downstream site (PAL018 also had the most steady 24-hour streamflow). There was a fairly large diel change $(8.7 \mathrm{mg} / \mathrm{L})$ in DO at PAL097, which was somewhat surprising because this site is more than $25 \mathrm{~km}$ downstream from the discharges of the WWTPs at Palouse and Potlatch (fig. 1), which have much smaller discharges than those from the Moscow and Pullman WWTPs. Nutrient and chloride concentrations also were low at PAL097 (river kilometer 156) (figs. 4 and 5 and Appendix B). Although there is aquatic plant activity in the reach, the large diel change in DO at PAL097 also may be a result of the extreme low-flow conditions at this site: the reach went dry sometime during the following 2 weeks.

The State's standard for maximum $\mathrm{pH}$ was exceeded during the 24-hour synoptic study at all three sites on the Palouse River (Appendix B). These three sites met the criteria during the early-morning synoptic sampling; the high $\mathrm{pH}$ levels generally were observed between noon and midnight at these sites.

\section{FACTORS CONTROLLING GROWTH OF BENTHIC ALGAE}

The growth of benthic algae, represented by the concentration of chlorophyll $a$, is an indicator of the primary productivity of a stream. Benthic algae were studied at sites in the basin in conjunction with physical and chemical variables to determine what variables, or combination of variables, most influence algal growth on both large and small scales. A combination of multiple regression and molar ratios of inorganic nitrogen to orthophosphate $(\mathrm{N}: \mathrm{P}$ ratios) was used to determine the extent to which individual factors limit growth of benthic algae during low streamflows in the basin. Multiple regression was used to identify which variables, or combination of variables, most account for the variability in chlorophyll $a$; the variables included in the regression are considered to be most limiting to growth of benthic algae.
$\mathrm{N}: \mathrm{P}$ ratios were used as a preliminary assessment of nutrient limitation: ratios above a given threshold level indicate possible phosphorus limitation, and ratios below that level may indicate nitrogen limitation. An N:P ratio less than 16 is commonly considered to be the threshold between nitrogen and phosphorus limitation for aquatic plant communities (Welch, 1980). The ratio for algae ranges from 10:1 to 15:1 (Forsberg, 1980) and, in general, streams in the western United States are nitrogen limited (Omernik, 1976) whether in arid regions (Cole and Batchelder, 1969) or in forested areas (Gregory, 1980). $\mathrm{N}: \mathrm{P}$ ratios for sites in the basin in August 1994 are shown in figure 8 .

\section{Palouse River}

Chlorophyll $a$ in the Palouse River generally increased downstream from $0.7 \mathrm{mg} / 0.1 \mathrm{~m}^{2}$ (milligrams per tenth of square meter) in the forested headwaters to $14 \mathrm{mg} / 0.1 \mathrm{~m}^{2}$ at PAL018 (river kilometer 30), with a moderate additional increase in chlorophyll $a$ below the confluence with the South Fork Palouse River and a subsequent decrease, and then an increase downstream to a high at PAL018 (fig. 9); this pattern is similar to that observed for ammonia concentrations (fig. 5). The growth of benthic algae measured at PIN008 (river kilometer 143) and REB000 (river kilometer 84), on two of the major agricultural tributaries, was higher than at all of the sites on the Palouse River except for PAL018, which is downstream from the inflows of these tributaries (fig. 1). The chlorophyll $a$ concentration at REB000 was $11 \mathrm{mg} / 0.1 \mathrm{~m}^{2}$ and at PIN008 was $16 \mathrm{mg} / 0.1 \mathrm{~m}^{2}$.

Figure 10 shows the relations of chlorophyll $a$ to water velocity, water temperature, solar energy, and inorganic nitrogen. Multiple regression indicated that chlorophyll $a$ in the Palouse River system, including the two forested and two tributary sites (and excluding the sites on South Fork system), was most influenced by inorganic nitrogen (nitrate plus nitrite plus ammonia) and solar energy (kilocalories, kcal) with an overall $\mathrm{r}^{2}$ in the multiple regression model of 0.87 (table 3 , model 1). Chlorophyll $a$ was not significantly correlated $(P=<0.05)$ with orthophosphate. This indicates that, overall, nitrogen was the nutrient most limiting to the growth of benthic algae during the period of the study. The conclusion that nitrogen was limiting is supported by the generally low N:P ratios at all sites on the Palouse River (fig. 8). Nitrogen limitation is indicated whether or not the two sites in the forested headwaters were included in the model (table 3 , model 2). 


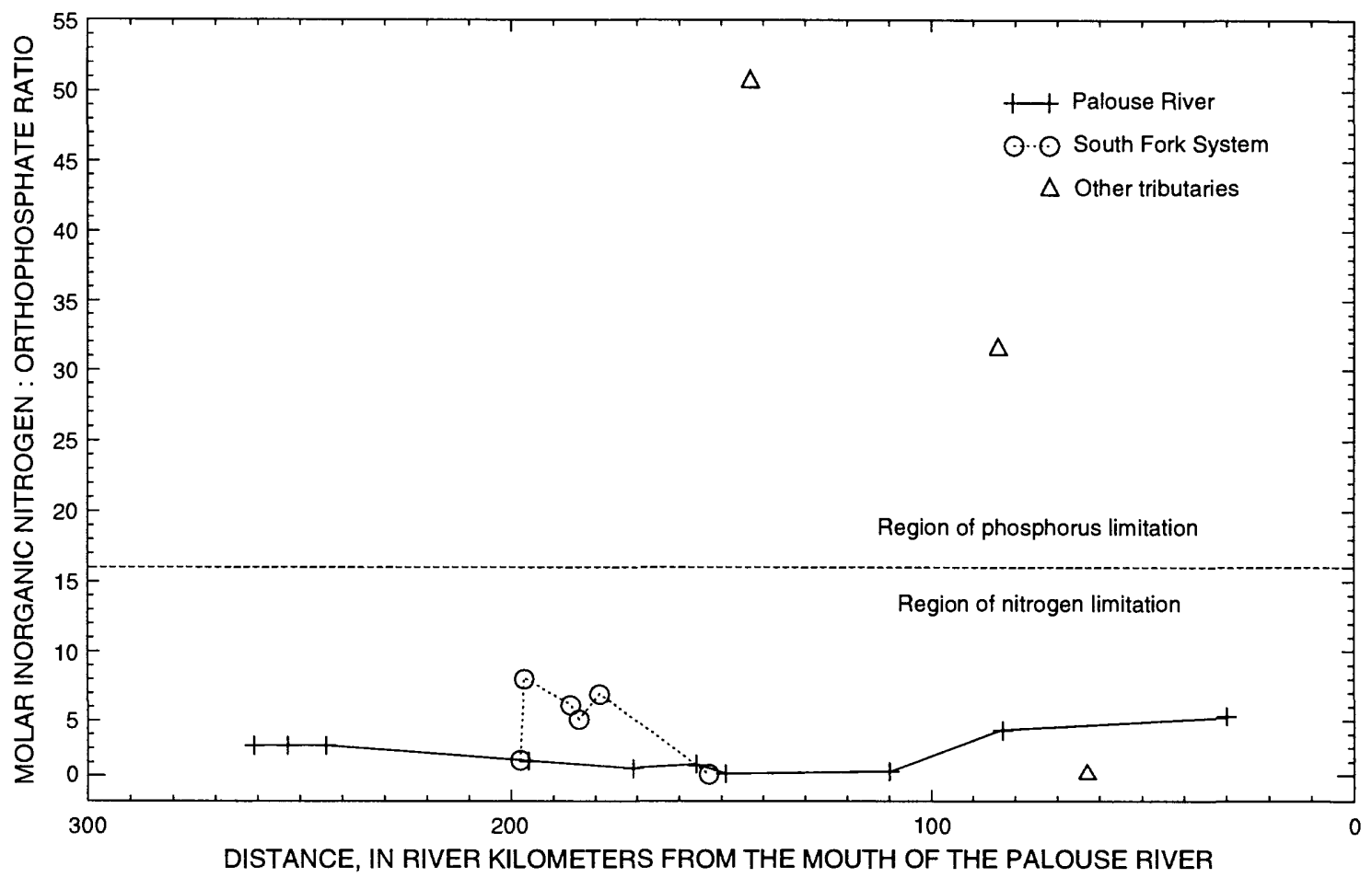

Figure 8. Molar ratios of inorganic nitrogen to orthophosphate for sites in the Palouse River Basin. Sites are listed in downstream order in table 1.

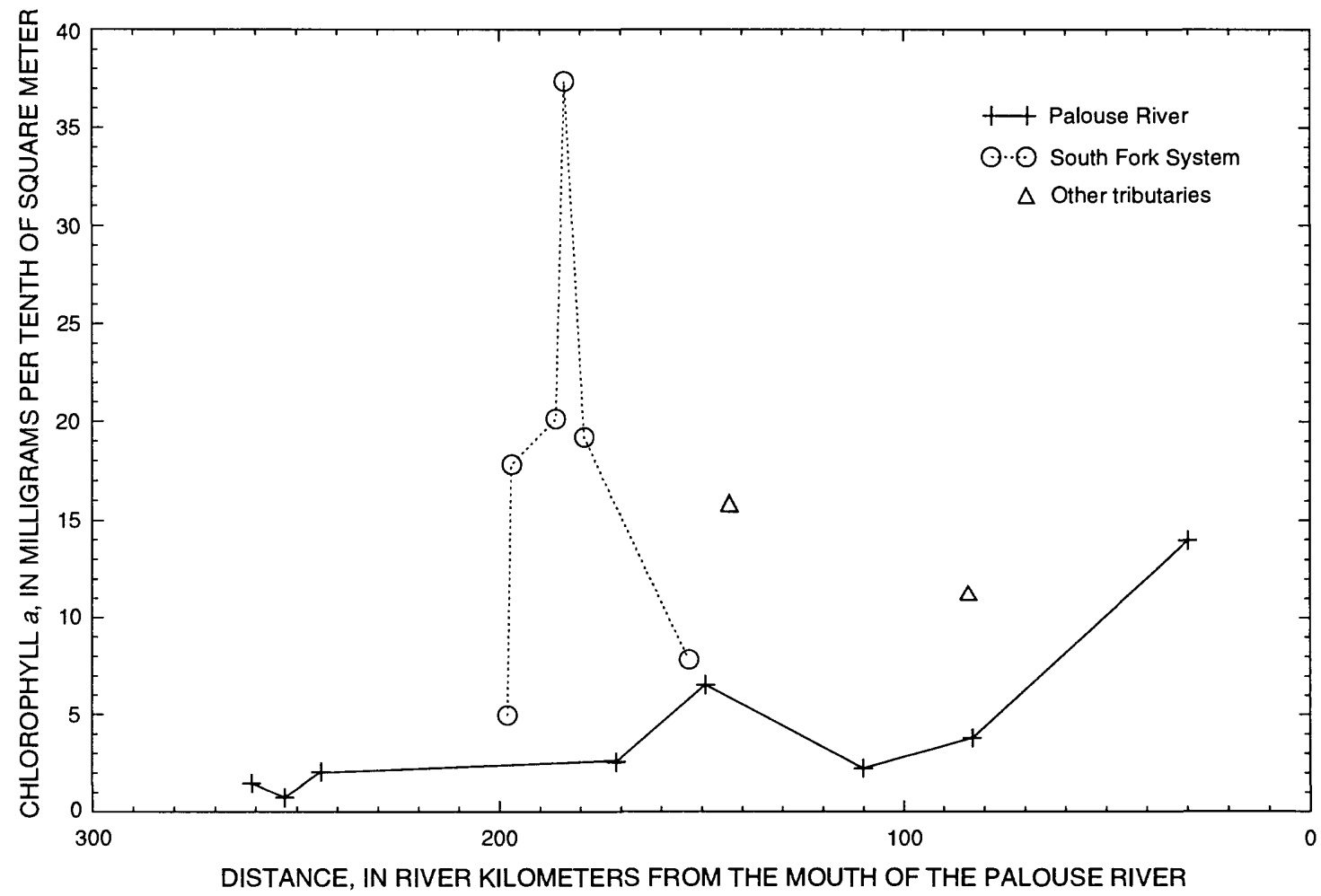

Figure 9. Concentrations of chlorophyll $a$ in benthic algae accrued on artificial substrates, during an 8-week colonization period, during low streamflow conditions at sites in the Palouse River Basin,1994. Sites are listed in downstream order in table 1. 

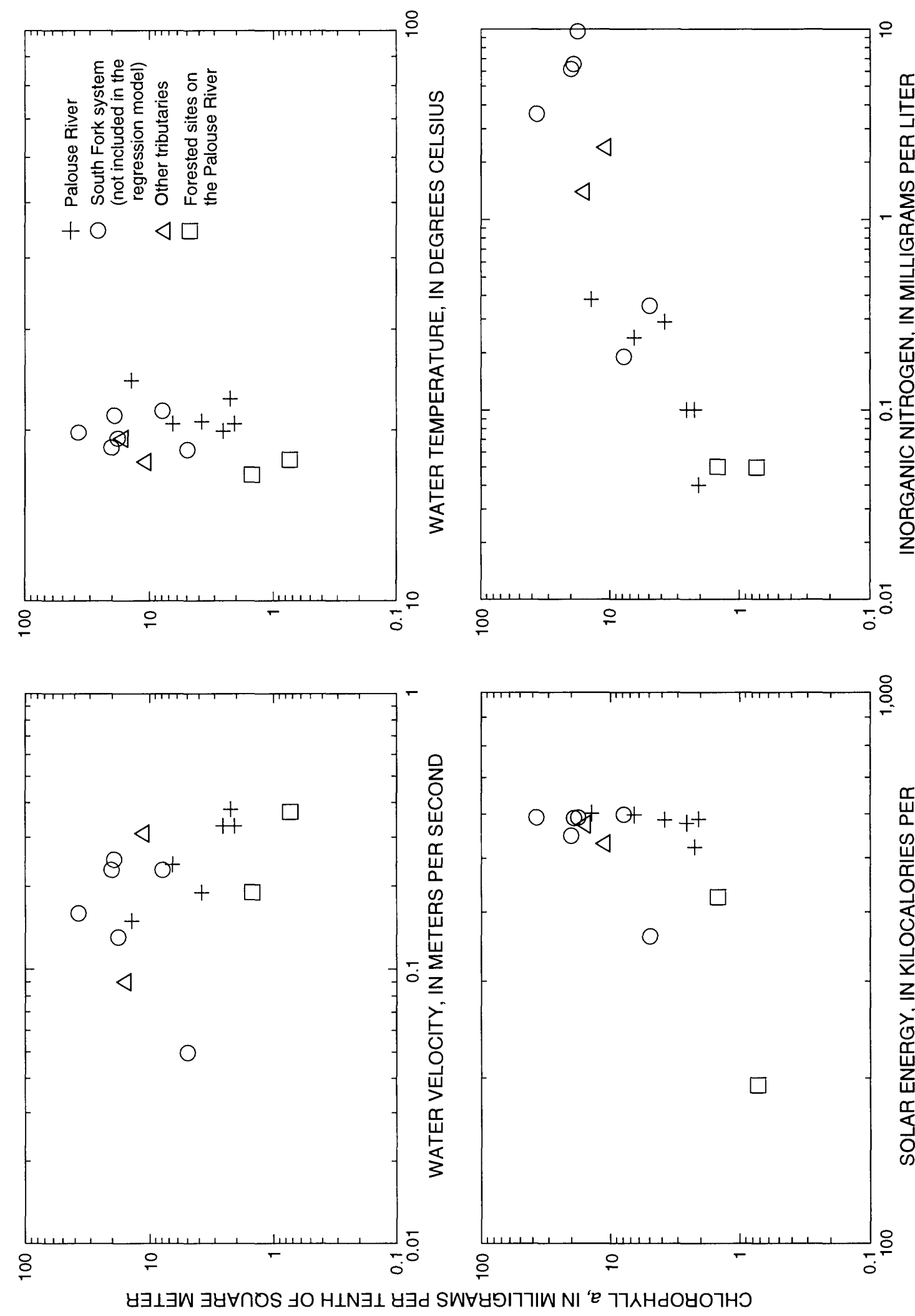

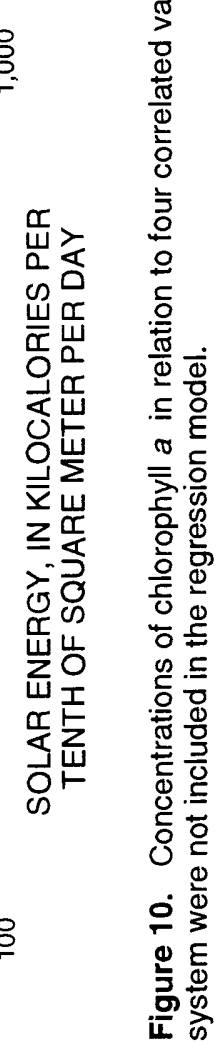


Table 3.--Statistical relationships between chlorophyll a concentrations and inorganic nitrogen concentrations and solar energy at sites in the Palouse River Basin during low streamflow, July-September 1994

[n, number of sites included in the model; $r$, correlation coefficient for the variable in the correlation matrix; $r^{2}$, correlation coefficient for the regression model; $P$, probability value]

Sites included

in the model
Variables included

in the model $(r)$
Regression model ${ }^{(1)}$ $r^{2} \quad P$

\section{Model 1}

Palouse River $\quad 10$

and other

tributaries inorganic nitrogen $(0.75)$

solar energy $(0.66)$

\section{Model 2}

Palouse River

and other

tributaries,

excluding

forested sites
8

inorganic nitrogen $(0.75)$ $\log _{10}($ chlorophyll $a)=0.60$

0.87

$+0.53 \log _{10}$ (inorganic nitrogen)

+0.003 (solar energy)
0.003

$\log _{10}($ chlorophyll $a)=2.4$

0.72

0.005 

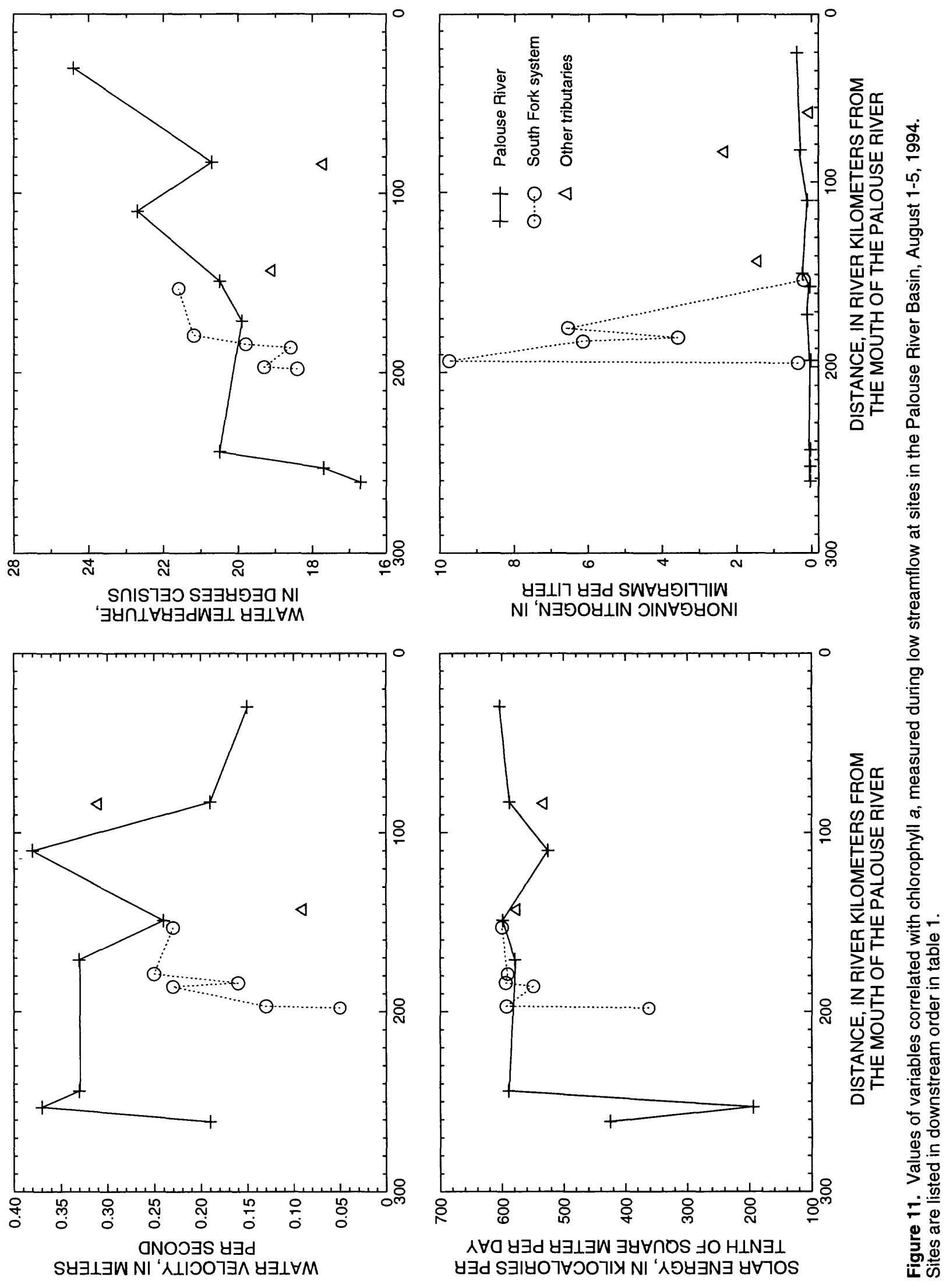
Welch and others, 1989; Munn and others, 1989), and water temperature was positively correlated $(r=0.77)$ with chlorophyll $a$ for sites on the main channel Palouse River (excluding the two sites on tributaries). Although the changes in water temperature were not as pronounced as the changes in solar energy, the scope of their influences may be similar: growth of benthic algae and water temperature both were low at the forested headwaters sites (fig. 9 and 11). Although temperature continued to increase downstream, the increases were small until PAL018 (river kilometer 30). When the two tributary sites were included in the analysis, temperature was not a significant variable whether or not the forested headwaters sites were included; this is because the two tributary sites had low water temperatures but elevated concentrations of chlorophyll $a$, altering the overall relation.

Water velocity was negatively correlated $(r=-0.64)$ with chlorophyll $a$ for all sites excluding the South Fork system. This relation is more complicated to explain: it is generally accepted that because increased water velocity allows nutrients to be delivered at a faster rate, primary productivity increases until scour occurs (McIntire and others, 1964). However, Borchardt (1994) demonstrated that under laboratory conditions, the productivity of one species of filamentous algae (Spirogyra fluviatilis) increases with increased velocity, but then decreases above moderate velocities. Other filamentous algae ( $\mathrm{Cla}$ dophora species) were present at many sites in the basin. Borchardt postulated that the relation between algal growth and velocity may differ greatly among species, and the negative overall relation observed for the Palouse River (fig. 10) may result from lower optimum velocities for the different algal species present. Another possible explanation is that the lower water velocities in the Palouse River may be associated with higher water temperatures that might increase plant metabolism and result in higher measured concentrations of chlorophyll $a$.

\section{South Fork System}

Growth of benthic algae was higher in the South Fork system than in the Palouse River and the other tributaries (fig. 9). Chlorophyll $a$ concentrations increased from $5.0 \mathrm{mg} / 0.1 \mathrm{~m}^{2}$ above the Moscow WWTP to a high of $37 \mathrm{mg} / 0.1 \mathrm{~m}^{2}$ between the Moscow and Pullman WWTPs, then decreased downstream through the remainder of the South Fork system. Surprisingly, growth of benthic algae increased below the Moscow WWTP but did not increase below the Pullman WWTP. However, aquatic plant beds (composed mostly of filamentous algae, possibly Cladophora species, and a mixture of submerged aquatic vascular plants) were prolific from SFP018 (river kilometer 179) downstream to SFP002 (river kilometer 153). Growth of benthic algae at SFP002 was similar to growth at PAR007 (river kilometer 198), the site above the Moscow WWTP; however, the artificial substrates at SFP002 were shaded by the aquatic macrophytes for part of the colonization period, a situation that did not occur at any other site.

Chlorophyll $a$ at sites in the South Fork system was not significantly correlated (at probability value $P=<0.05$ ) with inorganic nitrogen, orthophosphate, or any of the physical variables measured whether or not SFP002 was included in the statistical analysis. Therefore, although the small sample size limits conclusions for the South . Fork system, growth of benthic algae does not appear to be limited by any of the factors considered. Among the variables measured, inorganic nitrogen had the highest correlation coefficient with chlorophyll $a(r=0.80, P=0.06)$, a better correlation than that observed for orthophosphate $(r=0.64, P=0.17)$. This is supported by the low N:P ratios on the South Fork system (fig. 8). However, there was not a significant correlation between growth of benthic algae and inorganic nitrogen or orthophosphate for the South Fork system because the nutrient loading in the South Fork system exceeded the nutrient requirements of the aquatic plants. This has been documented in other streams affected by a combination of urban point sources of nutrients and agricultural runoff (Kilkus and others, 1975; Moore, 1977; Munn and others, 1989).

The use of artificial substrates for assessing growth of benthic algae in the South Fork system apparently did not accurately reflect instream primary productivity in that part of the basin. The relation between nutrients and aquatic plant growth in the South Fork system can be analyzed by identifying longitudinal changes in both nutrient concentrations and plant communities and relating these changes to instream processes. Although concentrations of both inorganic nitrogen and orthophosphate increased below the WWTPs, inorganic nitrogen was lost at a much faster rate than orthophosphate (fig. 5). This loss of nitrogen cannot be fully explained by uptake by the benthic algae communities because during the period of benthic algae colonization on the artificial substrates, extensive aquatic plant beds developed in the South Fork system from the Pullman WWTP to the confluence with the Palouse River, and chlorophyll $a$ decreased to relatively low levels downstream from the Pullman WWTP. Benthic algae remained an important component of the stream system, but the shift to a macrophyte-based plant community has a profound effect on instream productivity and nutrient dynamics and therefore on our interpretation of the data. 
The large biomass of the macrophytes may partially explain the rapid loss of nitrogen in this reach; however the macrophytes, and apparently the benthic algae, had relatively little impact on the concentrations of orthophosphate in the South Fork system.

\section{FACTORS AFFECTING NUTRIENT CONCENTRATIONS IN PARTS OF THE PALOUSE RIVER SYSTEM}

As previously discussed, uptake of nutrients by aquatic plants is a major factor controlling inorganic nitrogen and orthophosphate concentrations in the Palouse River system. Additional analyses of the chemical and physical data collected during both the synoptic and 24-hour studies provide a basis to extend the conceptual understanding of nutrient dynamics in parts of the Palouse River system. The following conclusions were derived from these analyses: (1) uptake by aquatic plants and denitrification remove inorganic nitrogen from the South Fork Palouse River during extremely low streamflows like those observed in summer 1994; and (2) the decrease in orthophosphate concentrations in the reach of the Palouse River from PAL092 (river kilometer 149), below the Colfax WWTP, to PAL052 (river kilometer 84) was caused by some combination of dilution by ground-water seepage, uptake by aquatic plants, and sorption to streambed and suspended sediments. These mitigating processes were active during the period of this study, but more data are needed to determine how regularly they occur in the river.

\section{Loss of Inorganic Nitrogen in the South Fork System}

During the 24-hour study conducted in August 1994, loss of inorganic nitrogen in the reach from SFP018 to SFP002 was almost complete (see fig. 1; Appendix B). The mean concentration of inorganic nitrogen in four samples collected during the 24-hour study at SFP018 was $6.7 \mathrm{mg} / \mathrm{L}$ compared with the mean concentration of $0.14 \mathrm{mg} / \mathrm{L}$ in four samples collected at SFP002. In contrast to inorganic nitrogen, only 20 percent of the orthophosphate was lost in the same reach: the average concentration of orthophosphate at SFP018 was $2.4 \mathrm{mg} / \mathrm{L}$ compared with $2.0 \mathrm{mg} / \mathrm{L}$ at SFP002. The molar ratio of the loss of inorganic nitrogen to the loss of orthophosphate was 29:1 for this reach, almost twice the ratio of $16: 1$ commonly used to represent the relative amounts of inorganic nitrogen and orthophosphate assimilated by aquatic plants (Welch and others, 1989; see also "Factors Controlling Growth of Benthic Algae" in this report). The loss of dissolved inorganic nitrogen in excess of the expected losses due to plant uptake was probably caused by denitrification.

Denitrification is the process by which bacteria convert nitrate to dissolved nitrogen and nitrous oxide gases, which are biologically inert forms of nitrogen. Denitrification occurs in the absence of oxygen. Denitrification as a probable loss mechanism for inorganic nitrogen is consistent with previous findings (Triska and Oremland, 1981; Christensen and others, 1990) and with the low dissolved oxygen concentrations observed at sites in the South Fork Palouse River during the 24-hour study (Appendix B). Even lower concentrations of dissolved oxygen than those measured during the 24-hour study probably occurred at locations along the South Fork Palouse River where the water was pooled because of low streamflows.

\section{Loss of Orthophosphate in the Palouse River Downstream from Colfax}

Dilution resulting from a combination of ground-water discharge to the river and leakage of water from the river to the ground-water system may have accounted for most of the decrease in the concentration of orthophosphate (which comprises most of the dissolved phosphorus) observed during August 1994 in the Palouse River between PAL092 (river kilometer 149), below the Colfax WWTP, and the two next sites downstream, PAL068 (river kilometer 110) and PAL052 (river kilometer 84). Dilution by ground water is indicated because concentrations of chloride, a conservative constituent, decreased along this reach of the river (fig. 6), and because there were no significant surface-water inflows to this reach during August 1994. Along this reach of the river there is a net loss of water from the river to the ground water, so dilution probably represents the net effects of gains and losses along the reach, with the losses exceeding the gains. Data are available to make a rough estimate of how much the concentration of orthophosphate in the river is reduced by dilution, based on the dilution of chloride.

A mass balance of chloride and water discharges, illustrated in figure 12 and with equations more completely developed in Appendix C, was used to compute ground-water discharge to the river and leakage of river water to the ground-water system. For simplicity, both ground-water discharge and leakage from the river are approximated as being uniform along the entire reach of the river. This combination of ground-water discharge and 


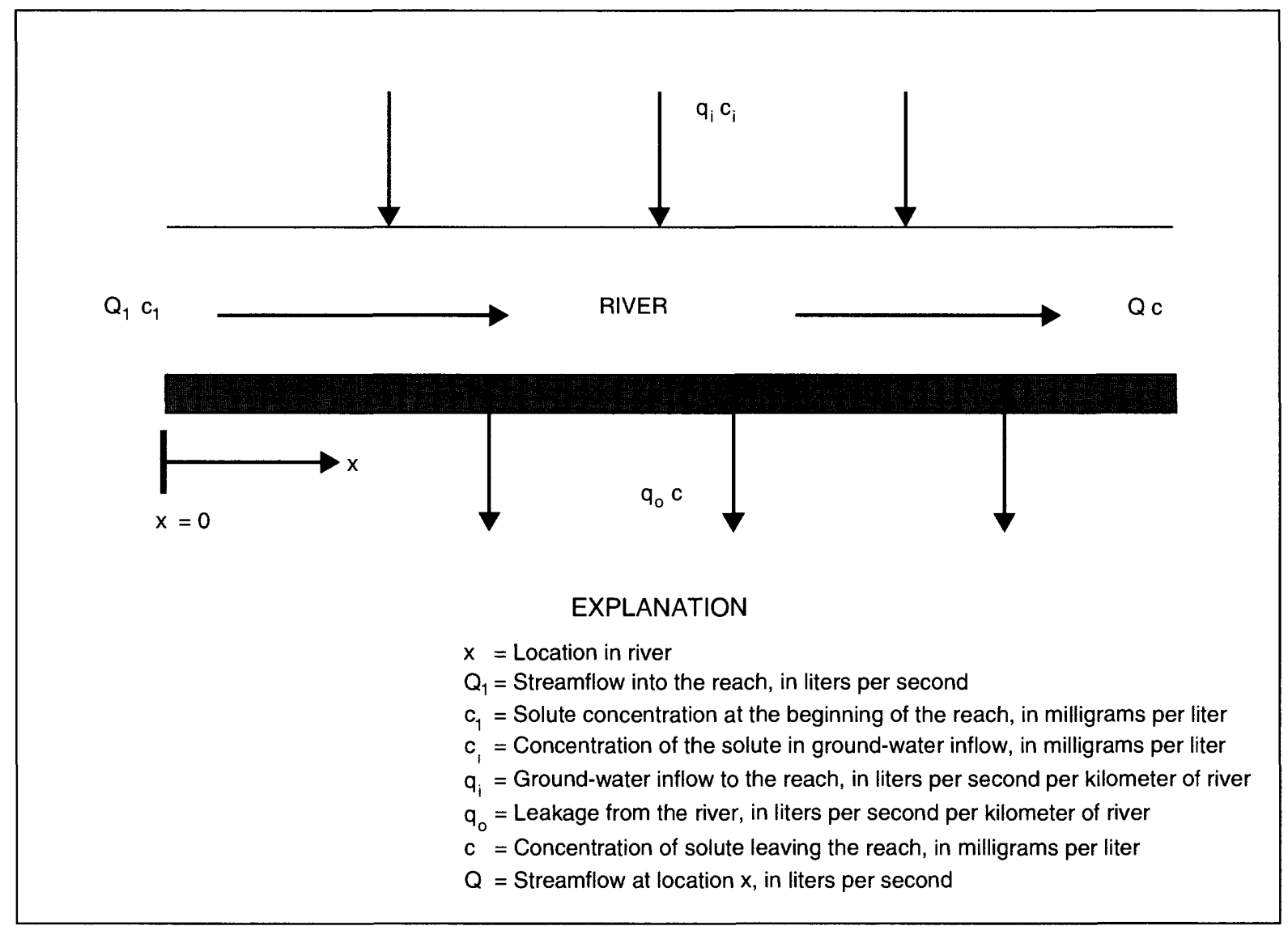

Figure 12. Schematic representation of movement of surface water, ground water, and a solute into and out of a river reach. 
river leakage results in dilution of chloride in the river water because the concentration of chloride in ground water discharging to the river is less than the concentration in the river along most of the reach. Other constituents, like orthophosphate, that are at low concentrations in the ground water also are diluted. Unlike chloride, orthophosphate is reactive and may sorb to or be released from suspended or bed sediments and is subject to uptake and release by aquatic plants. The concentration of orthophosphate is therefore governed by the combination of several complex factors. One approach is to use the results of the mass-balance computations with chloride to compute how the concentrations of orthophosphate would change if orthophosphate were subject only to dilution and were not reactive; the computed concentrations of orthophosphate are then compared with actual concentrations.

Of the input variables used in the chloride massbalance computations (table 4), the concentration of chloride in ground water discharging to the river was not known and was assumed to be $13 \mathrm{mg} / \mathrm{L}$, the concentration of chloride in the sample collected at PAL018 (river kilometer 30 ). Concentrations of chloride in the reach of the
Palouse River extending from PAL092 (river kilometer 149) to PAL018 appeared to be approaching an equilibrium concentration (fig. 6), and it is likely that the concentration of chloride in the river at PAL018 approaches the average concentration in the ground water discharging to the river. A concentration of $13 \mathrm{mg} / \mathrm{L}$ is also consistent with other data: it is between the average concentrations of $17.2 \mathrm{mg} / \mathrm{L}$ and $7.1 \mathrm{mg} / \mathrm{L}$ chloride in ground water in the Wanapum and Grande Ronde Basalt units (Steinkampf, 1989). Both basalt units are exposed in different parts of the Palouse River valley extending from PAL092 to PAL018 (Drost and Whiteman, 1986).

Ground-water discharge to the river and leakage of water from the river were computed for three reaches of the Palouse River between PAL092 and PAL052 (table 5). In addition to using $13 \mathrm{mg} / \mathrm{L}$ as the concentration of chloride in ground-water discharge to the river, the computations also were performed using the average concentrations of chloride in ground water in the Wanapum and Grande Ronde Basalts. (For some reaches, the average concentration of $17.2 \mathrm{mg} / \mathrm{L}$ in ground water in the Wanapum Basalt unit could not be used because it was

Table 4.--Measured and estimated variables used in mass-balance computations [L/s, liters per second; $\mathrm{mg} / \mathrm{L}$, milligrams per liter. Site codes are listed in table 1]

\section{$\underline{\text { Measured Variables }}$}

\begin{tabular}{llllll} 
& \multicolumn{2}{c}{ Streamflow $(\mathrm{L} / \mathrm{s})$} & & \multicolumn{2}{c}{ Concentration of chloride $(\mathrm{mg} / \mathrm{L})$} \\
\cline { 2 - 3 } $\begin{array}{l}\text { Reach } \\
\text { of Palouse } \\
\text { River }\end{array}$ & $\begin{array}{l}\text { Upstream } \\
\text { end }\left(Q_{I}\right)\end{array}$ & $\begin{array}{l}\text { Downstream } \\
\text { end }(Q)\end{array}$ & & $\begin{array}{l}\text { Upstream } \\
\text { end }\left(c_{1}\right)\end{array}$ & $\begin{array}{l}\text { Downstream } \\
\text { end }(c)\end{array}$
\end{tabular}

PAL092 to

207

164

59

26

PAL068

PAL092 to

207

42.5

59

14

PAL052

PAL068 to

164

42.5

26

14

PAL052

\section{Estimated Variables}

$c_{i}$ is the concentration of chloride in ground-water discharge when used in the chloride and water discharge mass-balance equations to compute ground-water discharge to the river and leakage from the river. See table 5 for values used.

$c_{i}=0.02 \mathrm{mg} / \mathrm{L}$, the concentration of orthophosphate in ground-water discharge, when the mass-balance equations were used to compute dilution of orthophosphate in the river. 
Table 5.--Results of mass-balance computations

[Site codes are listed in table 1. Values for all input variables, except the concentration of chloride in ground-water discharge to the river, are in table 4 . L/s, liters per second; $\mathrm{mg} / \mathrm{L}$, milligrams per liter]

\begin{tabular}{|c|c|c|c|c|c|c|}
\hline & \multirow{3}{*}{$\begin{array}{l}\text { Chloride } \\
\text { concentration } \\
\text { in ground- } \\
\text { water } \\
\text { discharge } \\
(\mathrm{mg} / \mathrm{L})\end{array}$} & \multicolumn{2}{|c|}{$\begin{array}{l}\text { Calculated values based } \\
\text { on chloride concentrations }\end{array}$} & \multirow{2}{*}{\multicolumn{3}{|c|}{$\begin{array}{l}\text { Concentration of orthophosphate } \\
\text { at downstream end of reach }\end{array}$}} \\
\hline & & \multirow{2}{*}{$\begin{array}{l}\text { Ground- } \\
\text { water } \\
\text { discharge } \\
\text { to river } \\
(\mathrm{L} / \mathrm{s})\end{array}$} & \multirow[b]{2}{*}{$\begin{array}{l}\text { Leakage } \\
\text { from river } \\
(\mathrm{L} / \mathrm{s})\end{array}$} & & & \\
\hline & & & & $\begin{array}{l}\text { Calcu- } \\
\text { lated } \\
(\mathrm{mg} / \mathrm{L})\end{array}$ & $\begin{array}{l}\text { Observed } \\
(\mathrm{mg} / \mathrm{L})\end{array}$ & $\begin{array}{l}\text { Difference } \\
(\mathrm{mg} / \mathrm{L})\end{array}$ \\
\hline \multicolumn{7}{|l|}{ Entire reach } \\
\hline PAL092 to & 13 & 163 & 327 & 0.06 & 0.17 & -0.11 \\
\hline PAL052 & 7.1 & 85.7 & 250 & 0.28 & 0.17 & 0.11 \\
\hline \multicolumn{7}{|c|}{$\frac{\text { Upper reach }}{\text { segment }}$} \\
\hline PAL092 to & 13 & 208 & 250 & 0.58 & 0.46 & 0.12 \\
\hline \multirow[t]{2}{*}{ PAL068 } & 7.1 & 166 & 208 & 0.74 & 0.46 & 0.28 \\
\hline & 17.2 & 256 & 298 & 0.44 & 0.46 & -0.02 \\
\hline \multicolumn{7}{|l|}{ Lower reach } \\
\hline PAL068 to & 13 & 109 & 231 & 0.05 & 0.17 & -0.12 \\
\hline PAL052 & 7.1 & 42.8 & 165 & 0.18 & 0.17 & 0.01 \\
\hline
\end{tabular}

larger than the concentration in the river at the downstream end of the reach.) The ground-water discharge and river leakage values were then used in the mass-balance equations to compute dilution of orthophosphate in the river. In these computations it was assumed that the concentration of orthophosphate in the ground-water recharge was $0.02 \mathrm{mg} / \mathrm{L}$, which is the median phosphorus concentration in ground water in the eastern Washington region that includes the Palouse River Basin (Jones and Wagner, 1995).

The calculated concentrations of orthophosphate in table 5 represent concentrations that would be found at the downstream end of each reach if the concentration of orthophosphate were affected only by dilution. If the calculated concentration is larger than the observed concentration, then other mechanisms also remove orthophosphate from the river water, which is expected. In some instances, however, the calculated concentrations were less than observed concentrations, indicating problems with using a highly simplified approach to estimate dilution of orthophosphate, or perhaps indicating net release of phosphorus from plants or the stream bed. Even considering these complicating factors, dilution probably still accounts for most of the loss of orthophosphate along this reach of the river.

For the reach of the river extending from PAL092 to PAL068, calculated concentrations of orthophosphate were larger than observed concentrations for two of the three concentrations of chloride used as input for the mass-balance computations. The Grande Ronde Basalt is exposed along most of this reach of the river (Drost and Whiteman, 1986), so the estimated value of the concentration of chloride in the ground-water discharge to the stream is probably in the range of $7.1 \mathrm{mg} / \mathrm{L}$ to $13 \mathrm{mg} / \mathrm{L}$. Excess orthophosphate (calculated concentration larger than observed) implies removal of orthophosphate by another mechanism, such as uptake by aquatic plants. If the excess is removed by plant uptake, then inorganic nitrogen must be supplied from a source external to the river because plant growth in the reach is nitrogen limited and there is not enough nitrogen in the river at the upstream end of the reach (fig. 4) to support this amount of 
uptake of orthophosphate. Ground water is a possible source of the inorganic nitrogen needed to support uptake of the orthophosphate by plants. Assuming an uptake ratio of 16 moles of inorganic nitrogen to 1 mole of orthophosphate, the needed nitrogen could be supplied by groundwater discharge to the stream if concentration of nitrogen in ground water ranged from $0.68 \mathrm{mg} / \mathrm{L}$ (for an input concentration of $13 \mathrm{mg} / \mathrm{L}$ chloride) to $2.0 \mathrm{mg} / \mathrm{L}$ (for an input concentration of $7.1 \mathrm{mg} / \mathrm{L}$ chloride). Average nitrate concentrations are $3.7 \mathrm{mg} / \mathrm{L}$ and $0.96 \mathrm{mg} / \mathrm{L}$ for ground water in the Wanapum and Grande Ronde Basalt units (Steinkampf, 1989), a range of concentrations consistent with that needed to supply additional nitrogen required for phosphorus uptake by aquatic plants.

\section{SUMMARY}

The Palouse River Basin is located in semi-arid eastern Washington and northern Idaho. The headwaters of the river are in forested mountains, but the land use in the basin is mostly agricultural. Most of the population (and the largest two waste-water treatment plants (WWTPs) in the basin) is in the cities of Moscow and Pullman, both located in the South Fork Palouse River Basin. The water in the South Fork is mostly WWTP effluent during periods of low streamflow. More than 98 percent of the total nitrogen and phosphorus inputs to the Palouse River drainage basin are from nonpoint sources, such as fertilizers, atmospheric deposition, and livestock; however, most of these inputs never reach the river, and only about 5 percent of the nitrogen and 4 percent of the phosphorus input to the basin is exported in surface-water discharge during an average flow year. The export of nutrients from the basin may be less during a dry year such as 1994 than during a typical year.

During low streamflows, Moscow and Pullman WWTP discharges are the primary source of nutrients to Paradise Creek and the South Fork Palouse River; however, a large portion of these nutrients is removed from the water column: in July, the discharges of total nitrogen and total phosphorus at SFP002, the downstream site on the South Fork, were 6.5 percent and 35 percent of the combined discharges from the two WWTPs. The monthly mean discharges of total nitrogen at SFP002 were less than the combined discharges from the two WWTPs for all months except November through March, when nonpoint sources are dominant and there is less removal of nutrients by the aquatic plant uptake and denitrification.
Synoptic low-flow sampling was conducted August $1-5,1994$, between 5 a.m. and 9 a.m. at 19 sites in the basin in order to assess variations in nutrient concentrations and water-quality conditions during low streamflows and to compare sites influenced to varying degrees by WWTPs. In general, nutrient concentrations were higher at sites on the South Fork system than at sites on the Palouse River. Most of the dissolved nitrogen in the South Fork system is inorganic (contributed by the WWTPs) and readily available for uptake by aquatic plants, in contrast with the Palouse River, where most of the dissolved nitrogen is organic. Washington State's standards for minimum dissolved oxygen and maximum $\mathrm{pH}$ were not met throughout the basin, and the ammonia toxicity standard was exceeded at PAR006, on Paradise Creek downstream from the Moscow WWTP. PAR006 had the highest concentrations of nitrate $(7.4 \mathrm{mg} / \mathrm{L})$, nitrite $(0.57 \mathrm{mg} / \mathrm{L})$, and ammonia $(2.3 \mathrm{mg} / \mathrm{L})$ observed in the basin.

Concentrations decreased sharply from PAR006 to the confluence of Paradise Creek with the South Fork, but increased again below the Pullman WWTP. Orthophosphate also increased due to effluent from the Pullman WWTP, but ammonia did not. Below Pullman, nitrate, nitrite, and ammonia concentrations in the South Fork decreased to levels as low as those measured at sites on the upper Palouse River; however, orthophosphate concentrations remained high. Nutrients were removed primarily by aquatic plant uptake and denitrification.

A 24-hour study was conducted at five sites to determine the extent of diel swings in nutrient and dissolved oxygen concentrations as a result of aquatic plant productivity. Nutrient concentrations changed over a 24-hour period, especially at the two sites on the South Fork and the site below the Colfax WWTP, possibly as a result of diel variations in plant uptake combined with changes in streamflow and WWTP discharges. The lowest observed concentrations for any of the nutrients at the two South Fork sites were observed late in the afternoon, between 5 and 6 p.m., and the highest concentrations were between 5 a.m. and noon. There were larger 24-hour changes in concentrations of nitrate and nitrite at SFP018, $4 \mathrm{~km}$ below the Pullman WWTP, than at SFP002, $26 \mathrm{~km}$ further downstream, whereas concentrations of ammonia were essentially constant over the 24-hour period at both sites. Orthophosphate concentrations, however, changed during the 24-hour period at SFP002, while orthophosphate at SFP018 remained the same. 
The magnitude of diel swings in dissolved oxygen ranged from changes of $4.6 \mathrm{mg} / \mathrm{L}$ to $14.7 \mathrm{mg} / \mathrm{L}$ at the five 24-hour study sites, with the three sites affected by WWTPs having the largest swings, the lowest nighttime concentrations, and the most supersaturated afternoon concentrations of dissolved oxygen. Low concentrations were observed (less than $2 \mathrm{mg} / \mathrm{L}$ for several hours at both of the South Fork sites), probably forming locally anoxic zones where denitrification occurred.

Growth of benthic algae, represented by chlorophyll $a$ concentrations, was measured at 16 sites throughout the basin in order to identify the physical and chemical factors that most influence this growth in the Palouse River system during low streamflows. Growth of benthic algae was generally higher in the South Fork system and at the sites on Pine and Rebel Flat Creeks than in the Palouse River; it increased rapidly below the Moscow WWTP but did not increase below the Pullman WWTP. The growth of benthic algae at SFP002, the site above the confluence with the Palouse River, was similar to growth above the Moscow WWTP at the uppermost site on the South Fork system; however, the artificial substrate at SFP002 was partly shaded by aquatic macrophytes that developed during colonization period.

Inorganic nitrogen concentration was found to be the most statistically significant variable limiting growth of benthic algae in the basin. Regression models were developed for two subsets of the sites in the basin, using the physical and chemical variables significantly correlated $(P=<0.05)$ with chlorophyll $a$. Chlorophyll $a$ in the Palouse River system (excluding the South Fork sites) was correlated with inorganic nitrogen, but not with orthophosphate. Chlorophyll $a$ also was correlated with solar energy, but because growth of benthic algae at most sites in the basin does not appear to be light-limited, solar energy was an important factor only for the two forested sites on the Palouse River. Although water temperature and water velocity did not add to the overall significance of the regression models, each was significantly correlated $(P=<0.05)$ with chlorophyll $a$ for some subsets of the sites. Predictably, chlorophyll $a$ concentrations increased with increasing water temperatures in the basin except at the two tributary sites, which had low temperatures and elevated chlorophyll $a$ concentrations. The effect of water velocity on growth of benthic algae is commonly such that the rate of primary productivity increases with faster water velocities (until scour occurs) because nutrients are delivered at a faster rate; however, in the Palouse River, water velocity appeared to have the opposite effect on growth of benthic algae, possibly due to different (lower) optimum velocities for the plant species in the Palouse River, and (or) because water temperatures are higher in slower waters in the Palouse River system, leading to increased plant productivity. For sites in the South Fork system, chlorophyll $a$ was not significantly correlated $(P=<0.05)$ with any of the variables measured. The lack of correlation between growth of benthic algae and inorganic nitrogen or orthophosphate for the South Fork system is probably due to nutrient loading in excess of the nutrient requirements for aquatic plant growth.

On the basis of molar ratios of inorganic nitrogen (nitrate plus nitrite plus ammonia) to orthophosphate (N:P ratios) in the water column, nitrogen appeared to be the nutrient most limiting primary productivity at sites on the Palouse River and the South Fork system. However, phosphorus limitation was indicated at the sites on the tributaries (Pine and Rebel Flat Creeks), probably as a result of extensive cattle grazing and the resulting animal wastes at Pine Creek and nitrogen-rich shallow ground-water contributions to Rebel Flat Creek. The molar ratio of the loss of inorganic nitrogen to the loss of orthophosphate was 29:1 for the lower South Fork system, almost twice the 16:1 ratio of inorganic nitrogen and orthophosphate used by aquatic plants. The loss of inorganic nitrogen in excess of the expected losses by plant uptake probably was caused by denitrification. Denitrification occurs under low dissolved oxygen conditions, which were observed in the South Fork during the 24-hour study.

Below the confluence of the South Fork with the Palouse River, plant uptake and denitrification do not appear to be the primary mechanisms of nutrient removal. Decreasing concentrations of chloride downstream from the confluence indicate that South Fork Palouse River water, including the combined WWTP effluent from the Colfax, Pullman, and Moscow WWTPs, does not remain in the Palouse River past PAL052, about $65 \mathrm{~km}$ downstream from the confluence. There were no significant surface-water inflows to this reach during August 1994. Dilution resulting from a combination of ground-water discharge to the river and leakage of water from the river to the ground-water system accounts for most of the decrease in the concentration of orthophosphate in the reach below the Colfax WWTP. A mass balance of chloride and water discharges was used to compute ground-water discharge to the river and leakage of river water to the ground-water system. The concentration of chloride in ground water discharging to the river was less than the concentration in the river along most of the reach, and orthophosphate, which is at low concentrations in the ground water, also is diluted. Unlike chloride, however, phosphorus is reactive and may sorb to or be released from suspended or bed sediments and is subject to uptake 
and release by aquatic plants. However, these complicating factors probably account for only a small portion of the loss of orthophosphate, and dilution probably accounts for most of the loss of orthophosphate below the Colfax WWTP.

\section{CITED REFERENCES}

American Public Health Association, 1985, Standard methods for the examination of water and wastewater, 16th edition: Washington, D.C., American Public Health Association, 1,268 p.

Anderson, J.R., Hardy, E.E., Roach, J.T., and Witmer, R.E., 1976, A land use and land cover classification system for use with remote sensor data: U.S. Geological Survey Professional Paper 964, 28 p.

Borchardt, M.A., 1994, Effects of flowing water on nitrogen- and phosphorus-limited photosynthesis and optimum N:P ratios by Spirogyra fluviatilis (Charophyceae): Journal of Phycology, v. 30, p. 418-430.

Bowie, G.L., Mills, W.B., Porcella, D.B., Campbell, C.L., Pagenkopf, J.R., Rupp, G.L., Johnson, K.M., Chan, P.W.H., Gherini, S.A., and Chamberlin, C.E., 1985, Rates, constants, and kinetics formulations in surface water quality modeling, 2nd edition: U.S. Environmental Protection Agency, EPA 600-3-85-040, $455 \mathrm{p}$.

Christensen, P.B, Nielsen, L.P., Sorensen, J., Revsbech, N.P., 1990, Denitrification in nitrate-rich streams; diurnal and seasonal variation related to benthic oxygen metabolism: Limnology and Oceanography, v. 35 , no. 3 , p. $640-651$.

Cohn, T.A., Caulder, D.L., Gilroy, E.J., Zynjuk, L.D., and Summers, R.M., 1992, The validity of a simple statistical model for estimating fluvial constituent loads; an empirical study involving nutrient loads entering Chesapeake Bay: Water Resources Research, v. 28 , no. 9 , p. 2,353-2,363.

Cole, G.A., and Batchelder, G.L., 1969, Dynamics of an Arizona travertine-forming stream: Journal of the Arizona Academy of Science, v. 5, p. 271-283.
Drost, B.W., and Whiteman, K.J., 1986, Surficial geology, structure, and thickness of selected geohydrologic units in the Columbia Plateau, Washington: U.S. Geological Survey Water-Resources Investigations Report 84-4326, $11 \mathrm{pl}$.

Fairchild, G.W., Lowe, R.L., and Richardson, W.B., 1985, Algae periphyton growth on nutrient-diffusing substrates; an in situ bioassay: Ecology, v. 66, p. $465-472$.

Forsberg, C., 1980, Present knowledge on limiting nutrients: Cincinnati, Ohio, U.S. Environmental Protection Agency, EPA 44-15-81-010, p. 17.

Greene, K.E., Ebbert, J.C., and Munn, M.D., 1994, Nutrients, suspended sediment, and pesticides in streams and irrigation systems in the Central Columbia Plateau in Washington and Idaho, 1959-1991: U.S. Geological Survey Water Resources Investigations Report 94-4215, 125 p.

Gregory, S.V., 1980, Effects of light, nutrients, and grazing on periphyton communities in streams: Corvallis, Oregon State University: Ph.D. dissertation, 150 p.

Jones, J.L., and Wagner, R.J., 1995, Water-quality assessment of the Central Columbia Plateau in Washington and Idaho: analysis of available nutrient and pesticide data for ground water, 1942-1992: U.S. Geological Survey Water-Resources Investigations Report 94-4258, 119 p.

Joy, J., 1987, A water quality assessment and receiving water survey of the South Fork of the Palouse River at Pullman, September 1986: Washington State Department of Ecology, Water Quality Investigations Section, seg. 16-34-01, 40 p.

Kilkus, S.P., LaPerriere, J.D., and Backmann, R.W., 1975, Nutrients and algae in some central Iowa streams: Journal of the Water Pollution Control Federation, v. 47 , p. $1,870-1,879$.

McIntire, C.D., Garrison, R.L., Phinney, H.K., and Warren, C.E., 1964, Primary production in laboratory streams: Limnology and Oceanography, v. 9, p. $92-102$. 
McIntire, C.D., and Phinney, H.K., 1965, Laboratory studies of periphyton production and community metabolism in lotic environments: Ecological Monographs, v. 35, p. 237-258.

Moore, J.W., 1977, Some factors affecting algal densities in a eutrophic farmland stream: Oecologia, v. 29, p. 257-267.

Munn, M.D., Osborne L.L., and Wiley M.J., 1989, Factors influencing periphyton growth in agricultural streams of central Illinois: Hydrobiologia, v. 174, p. 89-97.

National Atmospheric Deposition Program, 1985-91, NADP/NTN annual data summary, precipitation chemistry in the United States 1986-88: National Resource Ecology Laboratory, Colorado State University, Fort Collins, Colorado, annual summary for years indicated, variously paged.

National Oceanic and Atmospheric Administration, 1991, Climatological data annual summary Washington 1990, v. 94, no. 13: Asheville, North Carolina, 32 p.

Nelson, L.M., 1988, Surface-water resources of the Columbia Plateau in parts of Washington, Oregon, and Idaho: U.S. Geological Survey Water-Resources Investigations Report 88-4105, $4 \mathrm{pl}$.

Omernik, J.M., 1976, The influence of land use on stream nutrient levels: Corvallis, Oregon, U.S. Environmental Protection Agency, EPA 600-3-76-014, $68 \mathrm{p}$.

Pelletier, G.J., 1993, South Fork Palouse River total maximum daily load of ammonia: Washington State Department of Ecology, Environmental Investigations and Laboratory Services Program, Watershed Assessments Section, WA-34-1020 and WA-34-1025, $87 \mathrm{p}$.

Pringle, C.M., 1987, Effects of water and substratum nutrient supplies on lotic periphyton growth; an integrated bioassay: Canadian Journal of Fisheries and Aquatic Sciences, v. 44, p. 619-629.
Shelton, L.R., 1994, Field guide for collecting and processing stream-water samples for the National Water Quality Assessment Program: U.S. Geological Survey Open-File Report 94-455, 42 p.

Steinkampf, W.C., 1989, Water-quality characteristics of the Columbia Plateau regional aquifer system in parts of Washington, Oregon, and Idaho: U.S. Geological Survey Water-Resources Investigations Report 87-4242, $37 \mathrm{p}$.

Tanaka, H.H., Hansen, A.J., Jr., and Skrivan, J.A., 1974, Digital model study of ground-water hydrology, Columbia Basin Irrigation Project area, Washington: Washington State Department of Ecology Water-Supply Bulletin 40, 60 p.

Triska, F.J., and Oremland, R.S., 1981, Denitrification associated with periphyton communities: Applied and Environmental Microbiology, v. 42, no. 4, p. 745-748.

U.S. Department of Commerce, 1994, 1992 census of agriculture, Washington state and county data: U.S. Department of Commerce, AC92-A-47, v. 1, part 47, $332 \mathrm{p}$.

Washington State Administrative Code, 1992, Water quality standards for surface waters of the State of Washington, November 25, 1992, chapters 173-201A, $14 \mathrm{p}$.

Welch, E.B., 1980, Ecological effects of waste water: New York, Cambridge University Press, 337 p.

Welch, E.B., Horner, R.R., and Patmont, C.R., 1989, Prediction of nuisance periphytic biomass: a management approach: Water Resources, v. 23, no. 4 , p. 401-405. 
APPENDICES 


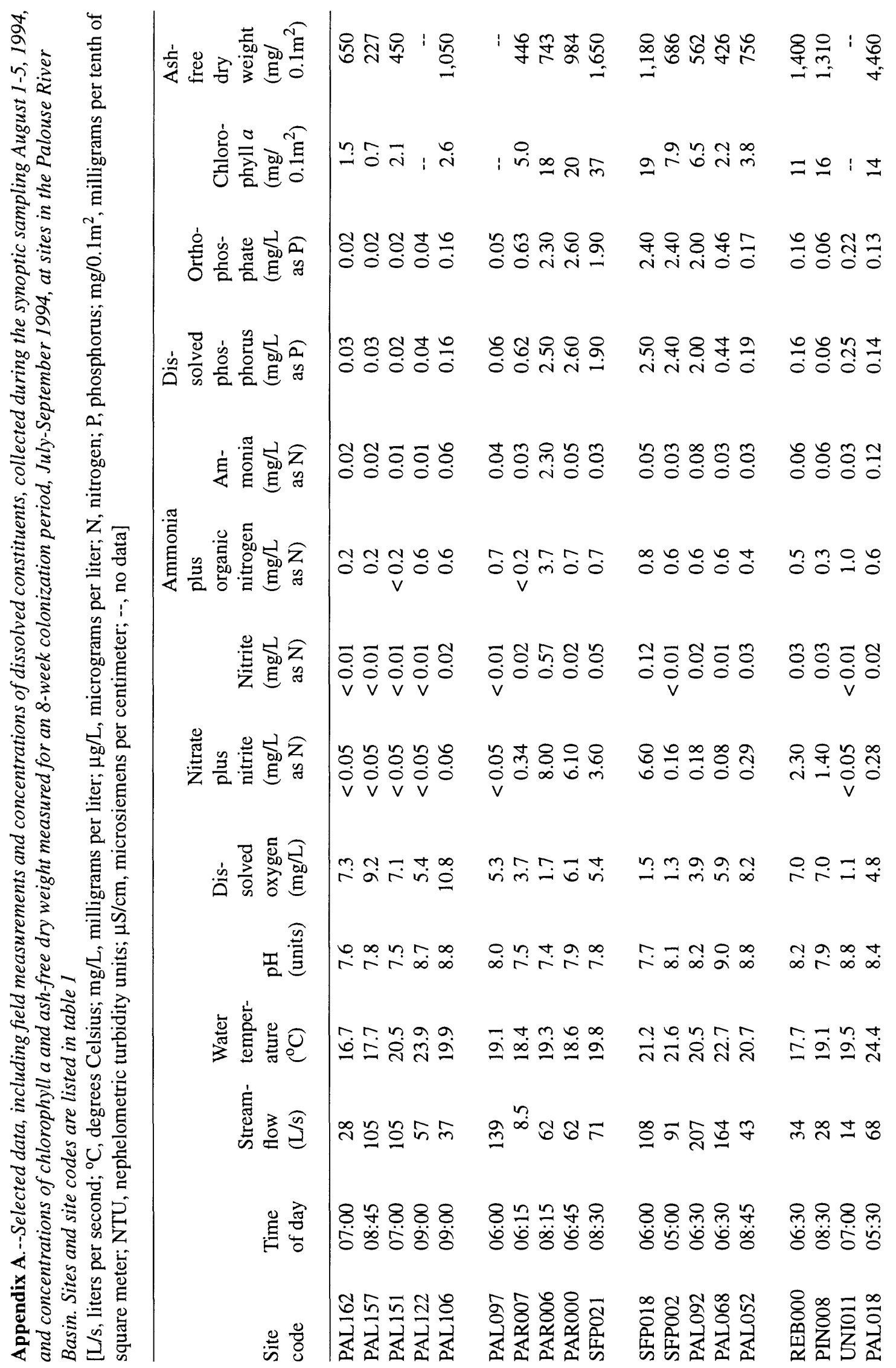




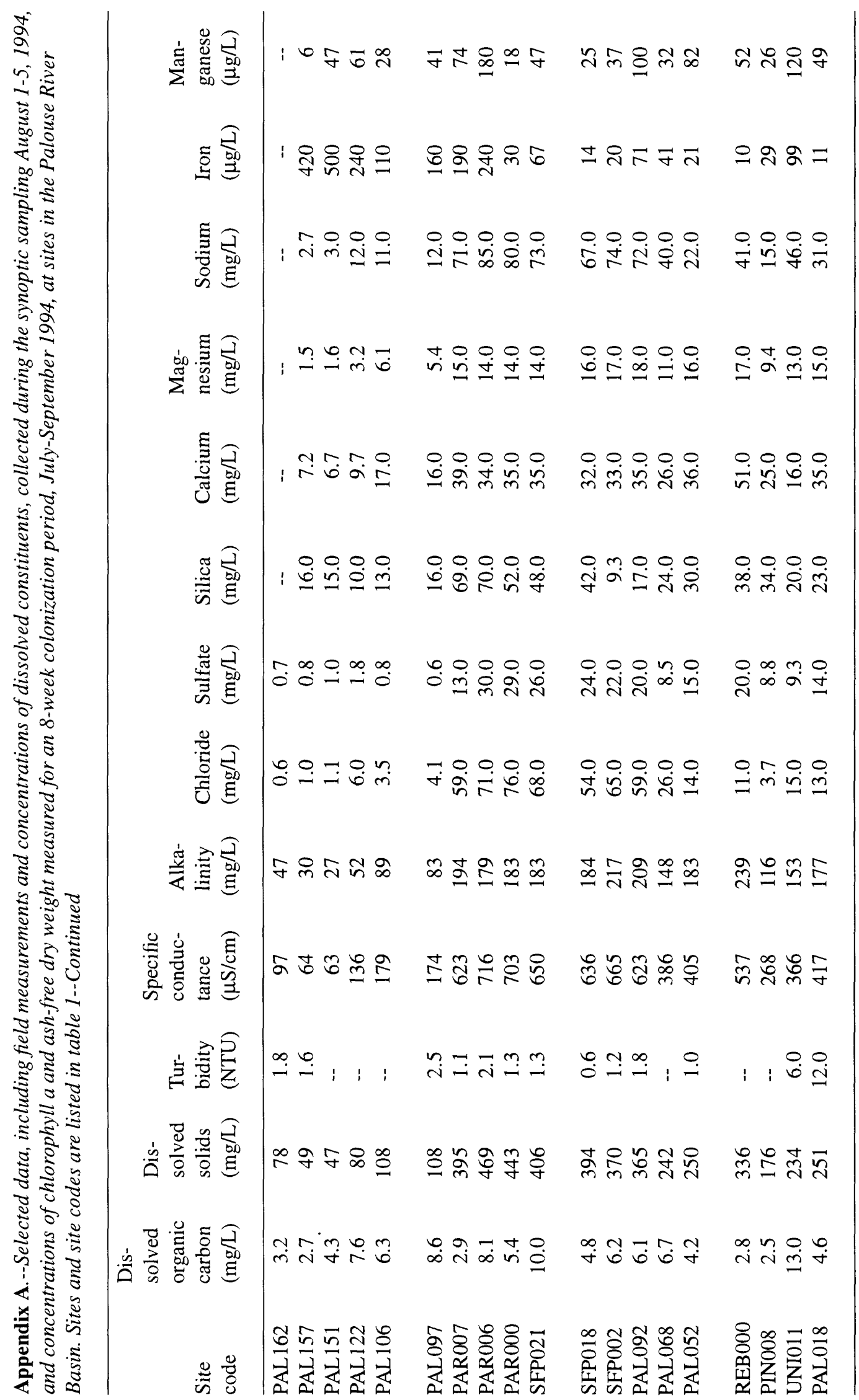


Appendix B.--Selected results from the 24-hour study conducted at five sites in the Palouse River Basin August 2-3, 1994

[Temp., water temperature; S.C., specific conductance; $\mu \mathrm{S} / \mathrm{cm}$, microsiemens per centimeter; DO, dissolved oxygen; mg/L, milligrams per liter; DOC, dissolved organic carbon; Ca, calcium; $\mathrm{Mg}$, magnesium; Na, sodium; $\mathrm{K}$, potassium; $\mathrm{SO}_{4}$, sulfate; $\mathrm{Fl}$, fluoride; $\mathrm{SiO}_{2}$, silica; $\mathrm{Fe}$, iron; $\mathrm{Mn}$, manganese; $\mu \mathrm{g} / \mathrm{L}$, micrograms per liter; --, no data]

\begin{tabular}{|c|c|c|c|c|c|c|c|c|c|c|}
\hline Time & $\begin{array}{l}\text { Temp. } \\
\left({ }^{\circ} \mathrm{C}\right)\end{array}$ & $\begin{array}{l}\text { S.C. } \\
(\mu S / \mathrm{cm})\end{array}$ & $\begin{array}{l}\mathrm{DO} \\
(\mathrm{mg} / \mathrm{L})\end{array}$ & $\begin{array}{l}\mathrm{pH} \\
\text { units }\end{array}$ & $\begin{array}{l}\text { Alka- } \\
\text { linity } \\
(\mathrm{mg} / \mathrm{L})\end{array}$ & $\begin{array}{l}\mathrm{DOC} \\
(\mathrm{mg} / \mathrm{L})\end{array}$ & $\begin{array}{l}\text { Nitrate } \\
(\mathrm{mg} / \mathrm{L})\end{array}$ & $\begin{array}{l}\text { Nitrite } \\
(\mathrm{mg} / \mathrm{L})\end{array}$ & $\begin{array}{l}\text { Ammonia } \\
(\mathrm{mg} / \mathrm{L})\end{array}$ & $\begin{array}{l}\text { Ortho- } \\
\text { phosphate } \\
(\mathrm{mg} / \mathrm{L})\end{array}$ \\
\hline \multicolumn{11}{|c|}{ SFP018 -- South Fork Palouse River at Armstrong Road near Pullman, Washington } \\
\hline 3:00 p.m. & 24.6 & 614 & 11.8 & 8.8 & 175 & -- & - & - & -- & -- \\
\hline 6:00 p.m. & 25.8 & 609 & 10.1 & 8.9 & 180 & 5.0 & 6.4 & 0.04 & 0.03 & 2.4 \\
\hline 9:00 p.m. & 24.8 & 623 & 6.4 & 8.7 & 178 & -- & -- & -- & -- & -- \\
\hline 12:00 a.m. & 23.3 & 633 & 3.3 & 8.3 & 183 & 5.1 & 6.4 & 0.05 & 0.05 & 2.5 \\
\hline 3:00 a.m. & 17.5 & 635 & 1.7 & 7.9 & 182 & -- & -- & -- & -- & -- \\
\hline 6:00 a.m. & 21.2 & 636 & 1.5 & 7.7 & 184 & 4.9 & 6.5 & 0.12 & 0.05 & 2.4 \\
\hline 9:00 a.m. & 21.2 & 635 & 4.7 & 7.8 & 178 & -- & -- & -- & -- & -- \\
\hline 12:00 p.m. & 23.8 & 628 & 11.8 & 8.5 & 180 & 4.8 & 6.9 & 0.16 & 0.04 & 2.4 \\
\hline 3:30 p.m. & -- & -- & 12.9 & -- & -- & -- & -- & -- & -- & -- \\
\hline \multicolumn{11}{|c|}{ SFP002 -- South Fork Palouse River at Colfax, Washington } \\
\hline 5:00 p.m. & 26.9 & 622 & 13.1 & 9.4 & 203 & 6.4 & 0.02 & $<0.01$ & 0.03 & 1.4 \\
\hline $8: 00$ p.m. & 26.4 & 626 & 7.1 & 9.4 & -- & -- & -- & -- & -- & -- \\
\hline 11:00 p.m. & 24.3 & 644 & 1.6 & 9.0 & 210 & 6.0 & 0.07 & $<0.01$ & 0.04 & 1.7 \\
\hline 2:00 a.m. & 22.7 & 659 & 1.1 & 8.6 & 214 & -- & -- & -- & -- & -- \\
\hline 5:00 a.m. & 21.6 & 665 & 1.3 & 8.1 & 217 & 6.2 & 0.16 & $<0.01$ & 0.03 & 2.4 \\
\hline 8:00 a.m. & 21.1 & 666 & 3.5 & 8.0 & 214 & -- & -- & -- & -- & -- \\
\hline 11:00 a.m. & 23.1 & 655 & 12.8 & 8.6 & 218 & 5.8 & 0.16 & $<0.01$ & 0.04 & 2.3 \\
\hline 2:00 p.m. & 26.5 & 631 & 15.8 & 9.1 & 203 & -- & -- & -- & -- & -- \\
\hline \multicolumn{11}{|c|}{ PAL097 -- Palouse River near Colfax, Washington } \\
\hline 3:00 p.m. & 32.4 & 151 & 12.3 & 9.9 & 61 & -- & -- & -- & -. & -- \\
\hline 6:00 p.m. & 31.6 & 142 & 8.0 & 9.8 & 59 & 9.9 & 0.05 & $<0.01$ & 0.06 & 0.07 \\
\hline 9:00 p.m. & 26.9 & 137 & 3.7 & 9.4 & 62 & -- & -- & -- & -- & -- \\
\hline 12:30 a.m. & 22.8 & 139 & 3.6 & 8.7 & 65 & 9.8 & $<0.05$ & $<0.01$ & 0.03 & 0.07 \\
\hline 3:00 a.m. & 20.8 & 157 & 3.9 & 8.2 & 73 & -- & -- & -- & -. & -- \\
\hline 6:00 a.m. & 19.1 & 171 & 5.3 & 8.0 & 83 & 8.6 & $<0.05$ & $<0.01$ & 0.04 & 0.05 \\
\hline 9:00 a.m. & 21.5 & 165 & 9.6 & 8.8 & 78 & -- & -- & -- & -- & -- \\
\hline 12:00 p.m. & 29.1 & 153 & 11.8 & 9.5 & 83 & 9.2 & $<0.05$ & $<0.01$ & 0.03 & 0.05 \\
\hline 3:00 p.m. & 32.9 & 152 & 10.8 & 10.0 & 63 & -- & -- & -- & -- & -- \\
\hline
\end{tabular}


Appendix B.--Selected results from the 24-hour study conducted at five sites in the Palouse River Basin August 2-3, 1994--Continued

\begin{tabular}{|c|c|c|c|c|c|c|c|c|c|c|}
\hline Time & $\begin{array}{l}\mathrm{Ca} \\
(\mathrm{mg} / \mathrm{L})\end{array}$ & $\begin{array}{l}\mathrm{Mg} \\
(\mathrm{mg} / \mathrm{L})\end{array}$ & $\begin{array}{l}\mathrm{Na} \\
(\mathrm{mg} / \mathrm{L})\end{array}$ & $\begin{array}{l}\mathrm{K} \\
(\mathrm{mg} / \mathrm{L})\end{array}$ & $\begin{array}{l}\mathrm{Cl} \\
(\mathrm{mg} / \mathrm{L})\end{array}$ & $\begin{array}{l}\mathrm{SO}_{4} \\
(\mathrm{mg} / \mathrm{L})\end{array}$ & $\begin{array}{l}\mathrm{Fl} \\
(\mathrm{mg} / \mathrm{L})\end{array}$ & $\begin{array}{l}\mathrm{SiO}_{2} \\
(\mathrm{mg} / \mathrm{L})\end{array}$ & $\begin{array}{l}\mathrm{Fe} \\
(\mu \mathrm{g} / \mathrm{L})\end{array}$ & $\begin{array}{l}\mathrm{Mn} \\
(\mu \mathrm{g} / \mathrm{L})\end{array}$ \\
\hline \multicolumn{11}{|l|}{ SFP018 } \\
\hline 3:00 p.m. & -- & -- & -- & -- & -- & -- & -- & -- & -- & -- \\
\hline 6:00 p.m. & 31 & 15 & 68 & 10 & 49 & 23 & 0.6 & 43 & 7 & 15 \\
\hline 9:00 p.m. & -- & -- & -- & -. & -- & -- & -- & -- & -- & -- \\
\hline 12:00 a.m. & 32 & 16 & 68 & 11 & 55 & 24 & 0.7 & 42 & 9 & 7 \\
\hline 3:00 a.m. & -- & -- & -- & -- & -- & -- & -- & -- & -- & -- \\
\hline 6:00 a.m. & 32 & 16 & 67 & 11 & 54 & 24 & 0.7 & 42 & 14 & 25 \\
\hline 9:00 a.m. & -- & -. & -- & -- & -- & -- & -- & -- & -- & -- \\
\hline 12:00 p.m. & 31 & 16 & 67 & 11 & 55 & 24 & 0.7 & 42 & 10 & 21 \\
\hline 3:30 p.m. & -- & -- & -- & -- & -- & -- & -- & -- & -- & -- \\
\hline \multicolumn{11}{|l|}{ SFP002 } \\
\hline 5:00 p.m. & 30 & 16 & 74 & 10 & 67 & 22 & 0.7 & 11 & 27 & 36 \\
\hline 8:00 p.m. & -- & -- & -- & -- & -- & -- & -- & -- & -- & -- \\
\hline 11:00 p.m. & 31 & 17 & 74 & 11 & 67 & 22 & 0.7 & 12 & 30 & 32 \\
\hline 2:00 a.m. & -- & -- & -- & -- & -- & -- & -- & -- & -- & -- \\
\hline 5:00 a.m. & 33 & 17 & 74 & 11 & 65 & 22 & 0.8 & 9 & 20 & 37 \\
\hline 8:00 a.m. & -- & -- & -- & -- & -- & -- & -- & -- & -- & -- \\
\hline 11:00 a.m. & 32 & 18 & 73 & 10 & 65 & 22 & 0.7 & 8 & 20 & 43 \\
\hline 2:00 p.m. & -- & -- & -- & -- & -- & -- & -- & -- & -- & -- \\
\hline \multicolumn{11}{|l|}{ PAL097 } \\
\hline 3:00 p.m. & -- & -- & -. & -- & -- & -- & -- & -- & -- & -- \\
\hline 6:00 p.m. & 11 & 2.5 & 11 & 3.2 & 3.9 & 0.5 & 0.2 & 15 & 140 & 30 \\
\hline 9:00 p.m. & -- & -- & -- & - & -- & -- & -- & -- & -- & -- \\
\hline 12:30 a.m. & 12 & 3.4 & 11 & 3.6 & 4.1 & 0.6 & 0.2 & 17 & 190 & 52 \\
\hline 3:00 a.m. & -- & -- & -- & -. & -- & -- & - & -- & -- & -- \\
\hline 6:00 a.m. & 16 & 5.4 & 12 & 3.7 & 4.1 & 0.6 & 0.2 & 16 & 160 & 41 \\
\hline 9:00 a.m. & -- & -- & -- & -- & -- & -- & -- & -- & -- & -- \\
\hline $12: 00$ p.m. & 14 & 4.2 & 12 & 3.1 & 4.0 & 0.5 & 0.2 & 14 & 170 & 30 \\
\hline 3:00 p.m. & -- & -- & -- & -- & -- & -- & -- & -- & -- & -- \\
\hline
\end{tabular}


Appendix B.--Selected results from the 24-hour study conducted at five sites in the Palouse River Basin August 2-3, 1994--Continued

\begin{tabular}{|c|c|c|c|c|c|c|c|c|c|c|}
\hline Time & $\begin{array}{l}\text { Temp. } \\
\left({ }^{\circ} \mathrm{C}\right)\end{array}$ & $\begin{array}{l}\text { S.C. } \\
(\mu S / \mathrm{cm})\end{array}$ & $\begin{array}{l}\mathrm{DO} \\
(\mathrm{mg} / \mathrm{L})\end{array}$ & $\begin{array}{l}\mathrm{pH} \\
\text { units }\end{array}$ & $\begin{array}{l}\text { Alka- } \\
\text { linity } \\
(\mathrm{mg} / \mathrm{L})\end{array}$ & $\begin{array}{l}\text { DOC } \\
(\mathrm{mg} / \mathrm{L})\end{array}$ & $\begin{array}{l}\text { Nitrate } \\
(\mathrm{mg} / \mathrm{L})\end{array}$ & $\begin{array}{l}\text { Nitrite } \\
(\mathrm{mg} / \mathrm{L})\end{array}$ & $\begin{array}{l}\text { Ammonia } \\
(\mathrm{mg} / \mathrm{L})\end{array}$ & $\begin{array}{l}\text { Ortho- } \\
\text { phosphate } \\
(\mathrm{mg} / \mathrm{L})\end{array}$ \\
\hline \multicolumn{11}{|c|}{ PAL092 -- Palouse River below waste-water treatment plant at Colfax, Washington } \\
\hline 3:30 p.m. & 31.3 & 543 & 16.0 & 9.2 & 187 & -- & -- & -- & -- & -- \\
\hline 6:30 p.m. & 29.3 & 541 & 11.0 & 9.1 & 189 & 6.7 & 0.20 & 0.02 & 0.07 & 1.3 \\
\hline 9:30 p.m. & 25.7 & 565 & 4.6 & 8.9 & 191 & -- & -- & -- & -- & -- \\
\hline 1:00 a.m. & 22.5 & 586 & 2.5 & 8.5 & 196 & 6.5 & 0.36 & 0.03 & 0.09 & 1.6 \\
\hline 3:30 a.m. & 21.5 & 595 & 2.7 & 8.4 & 198 & -- & -- & -- & -- & -- \\
\hline 6:30 a.m. & 20.5 & 623 & 3.9 & 8.2 & 209 & 6.1 & 0.16 & 0.02 & 0.08 & 2.0 \\
\hline 9:30 a.m. & 22.3 & 618 & 9.1 & 8.4 & 203 & -- & -- & -- & -- & -- \\
\hline $12: 30$ p.m. & 29.2 & 585 & 16.7 & 8.8 & 205 & 6.3 & 0.13 & 0.02 & 0.10 & 1.8 \\
\hline 3:30 p.m. & 32.4 & 565 & 16.4 & 9.3 & 202 & -. & -- & -- & -- & -- \\
\hline \multicolumn{11}{|c|}{ PAL018 -- Palouse River at Hooper, Washington } \\
\hline 2:30 p.m. & 31.0 & 400 & 9.4 & 8.8 & 185 & -- & -- & -- & -- & -- \\
\hline 5:30 p.m. & 31.1 & 399 & 8.8 & 8.8 & 185 & 5.0 & 0.22 & 0.02 & 0.06 & 0.11 \\
\hline 8:30 p.m. & 28.9 & 411 & 7.0 & 8.7 & 169 & -- & -- & -- & -- & -- \\
\hline 11:30 p.m. & 28.6 & 414 & 5.2 & 8.6 & 187 & 4.8 & 0.21 & 0.02 & 0.11 & 0.12 \\
\hline 3:00 a.m. & 25.1 & 414 & 5.0 & 8.4 & 178 & -- & -- & -- & -- & -- \\
\hline 5:30 a.m. & 24.4 & 417 & 4.8 & 8.4 & 186 & 4.6 & 0.26 & 0.02 & 0.12 & 0.13 \\
\hline 9:00 a.m. & 25.3 & 411 & 7.5 & 8.6 & 180 & -- & -- & -- & -- & -- \\
\hline $11: 30$ a.m. & 28.5 & 404 & 8.9 & 8.9 & 184 & 5.0 & 0.27 & 0.02 & 0.07 & 0.13 \\
\hline
\end{tabular}


Appendix B.--Selected results from the 24-hour study conducted at five sites in the Palouse River Basin August 2-3, 1994--Continued

\begin{tabular}{|c|c|c|c|c|c|c|c|c|c|c|}
\hline Time & $\begin{array}{l}\mathrm{Ca} \\
(\mathrm{mg} / \mathrm{L})\end{array}$ & $\begin{array}{l}\mathrm{Mg} \\
(\mathrm{mg} / \mathrm{L})\end{array}$ & $\begin{array}{l}\mathrm{Na} \\
(\mathrm{mg} / \mathrm{L})\end{array}$ & $\begin{array}{l}\mathrm{K} \\
(\mathrm{mg} / \mathrm{L})\end{array}$ & $\begin{array}{l}\mathrm{Cl} \\
(\mathrm{mg} / \mathrm{L})\end{array}$ & $\begin{array}{l}\mathrm{SO}_{4} \\
(\mathrm{mg} / \mathrm{L})\end{array}$ & $\begin{array}{l}\mathrm{Fl} \\
(\mathrm{mg} / \mathrm{L})\end{array}$ & $\begin{array}{l}\mathrm{SiO}_{2} \\
(\mathrm{mg} / \mathrm{L})\end{array}$ & $\begin{array}{l}\mathrm{Fe} \\
(\mu \mathrm{g} / \mathrm{L})\end{array}$ & $\begin{array}{l}\mathrm{Mn} \\
(\mu \mathrm{g} / \mathrm{L})\end{array}$ \\
\hline \multicolumn{11}{|l|}{ PAL092 } \\
\hline 3:30 p.m. & -- & -- & -- & -- & -- & -- & -- & -- & -- & -- \\
\hline 6:30 p.m. & 48 & 6.7 & 54 & 10 & 53 & 18 & 0.6 & 22 & $<3$ & $<1$ \\
\hline 9:30 p.m. & -- & -- & -- & -- & $\cdots$ & -- & -- & -- & -- & -- \\
\hline 1:00 a.m. & 33 & 17 & 68 & 10 & 52 & 19 & 0.6 & 22 & 84 & 110 \\
\hline 3:30 a.m. & -- & -- & -- & -- & -- & -- & -- & -- & -- & -- \\
\hline 6:30 a.m. & 35 & 18 & 72 & 11 & 59 & 20 & 0.6 & 17 & 71 & 100 \\
\hline 9:30 a.m. & -. & -. & -- & -- & - & -- & -- & -- & -. & -- \\
\hline $12: 30$ a.m. & 34 & 17 & 70 & 11 & 58 & 20 & 0.6 & 16 & 50 & 43 \\
\hline 3:30 a.m. & -- & -- & -- & -- & - & -- & - & -- & -- & -- \\
\hline \multicolumn{11}{|l|}{ PAL018 } \\
\hline 2:30 p.m. & -- & -- & -- & -- & -- & -- & -- & -- & -- & -- \\
\hline 5:30 p.m. & 35 & 15 & 30 & 6.1 & 12 & 14 & 0.3 & 23 & 26 & 21 \\
\hline $8: 30$ p.m. & - & -- & - & -- & -. & -. & - & -. & -- & -. \\
\hline 11:30 p.m. & 35 & 15 & 30 & 6.1 & 13 & 14 & 0.3 & 24 & 37 & 41 \\
\hline 3:00 a.m. & -. & -- & -- & -. & -. & -- & -- & -. & -- & -- \\
\hline 5:30 a.m. & 35 & 15 & 31 & 6.0 & 13 & 14 & 0.3 & 23 & 11 & 49 \\
\hline 9:00 a.m. & -- & -- & -. & -- & -- & -- & -- & - & -. & -. \\
\hline 11:30 a.m. & 35 & 15 & 30 & 6.0 & 13 & 14 & 0.3 & 24 & 29 & 32 \\
\hline
\end{tabular}




\section{APPENDIX C}

\section{Development of Mass-Balance Equations Used to Estimate Dilution of Orthophosphate in the Palouse River}

A simplified mass balance of water and chloride discharges was used to compute ground-water discharge to the river and leakage of river water to the ground-water system along the reach of the Palouse River from PAL092 to PAL052. The discharge and leakage values were then used in the mass-balance equations to compute dilution of orthophosphate in this reach of the river.

For the simplified mass-balance approach represented schematically in figure 11 , it is assumed that (1) there are no surface-water inflows to the reach (which is consistent with conditions in August 1994); (2) groundwater discharge to the river and leakage of water from the river are uniform along the entire reach $\left(q_{i}=q_{o}\right)$; and (3) the concentration of chloride in ground water discharging to the river is constant along the entire reach.

Equation 1 represents the conservation of chloride in the reach:

$$
\frac{d(Q c)}{d x}=q_{i} c_{i}-q_{o} c
$$

Equation 2 represents the conservation of water in the reach:

$$
\frac{d Q}{d x}=q_{i}-q_{o}
$$

In equations 1 and 2 ,

$Q=$ water discharge, in liters per second, at location x in the river;

$c=$ the concentration of chloride, in milligrams per liter, at location $\mathrm{x}$ in the river;

$q_{i}=$ ground-water discharge, in liters per second per kilometer, to the river;

$c_{i}=$ the concentration of chloride, in milligrams per liter, in ground water discharging to the river; and

$q_{o}=$ leakage of water, in liters per second per kilometer, from the river.

Using equations 1 and 2 , the mass-balance equations are developed for computing $c$ and $Q$ (equations 3 and 4 , respectively) and for computing $q_{i}$ and $q_{o}$ (equations 5 and 6 , respectively).

$$
Q \frac{d c}{d x}+c \frac{d Q}{d x}=q_{i} c_{i}-q_{o} c
$$

$Q \frac{d c}{d x}+c\left(q_{i}-q_{o}\right)=q_{i} c_{i}-q_{o} c$

$$
Q \frac{d c}{d x}=-q_{i}\left(c-c_{i}\right)
$$

let $C=c-c_{i}$

$$
\begin{aligned}
& Q \frac{d C}{d x}=-q_{i} C \\
& C=C_{1} e^{\frac{-q_{1} x}{Q}}
\end{aligned}
$$

$$
\text { at } \mathrm{x}=0, c=c_{1} \text { and } C=c_{1}-c_{i}
$$

$$
\text { therefore } C_{l}=c_{1}-c_{i}
$$

$$
c=\left(c_{1}-c_{i}\right) e^{\frac{-q_{1} x}{Q}}+c_{i}
$$

$$
Q=Q_{1}+\left(q_{i}-q_{o}\right) x
$$

$$
\begin{gathered}
\frac{c-c_{i}}{c_{1}-c_{i}}=e^{\frac{-q_{1} x}{Q}} \\
\ln \frac{c-c_{i}}{c_{1}-c_{i}}=\frac{-q_{i} x}{Q} \\
q_{i}=-\left(\frac{Q}{x}\right) \ln \frac{c-c_{i}}{c_{1}-c_{i}} \\
q_{o}=\frac{Q_{1}-Q}{x}+q_{i}
\end{gathered}
$$

